Historic, Archive Document

Do not assume content reflects current scientific knowledge, policies, or practices 




\section{PL A NTERS}

WHOLESALE

PRICE LIST

NUMBER 46

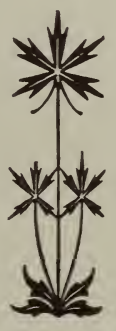

EST ABLISHED 1867

AUGUSTINE \& COMPANY NURSERYMEN NORMAL, ILLINOIS 


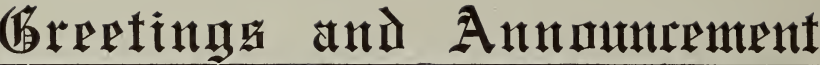

In presenting our forty-sixth Annual Price List, we desire to thank our patrons for their liberal patronage in the past, and to assure all that, as heretofore, QUALITY with us is the first consideration. Our line of stock is very complete and we have every modern facility to execute your orders carefully and well. If you are in need of anything not mentioned in this List, please correspond with us. We have not catalogued some three hundred varieties of fruit and ornamental plants that we grow, mostly rare and seldom called for varieties.

\section{LANDSCAPE GARDENING}

We are prepared to do all kinds of landscape work, furnish full plans and specifications. We have associated with us in this work one of the best Landscape Architects in the country, and are certain we can please you in thoroughly artistic and up to date work.

Guarantee of Genuineness-We exercise the greatest of care to have all stock pure and true to label, and we hold ourselves in readiness at all times to replace the stock that may prove untrue to label, or refund the money paid, when promptly notified, but it is mutually understood, and agreed, between ourselves and the purchaser, that our guarantee of genuineness shall in no case make us liable for any sum greater than that originally received for said trees or plants.

Responsibility-Our responsibility extends only to those purchasing direct from us. We are employing no agents to sell general nursery stock, and dealers purchasing stock from us sell upon their own responsibility. We have agents selling our SUDDUTH PEAR, but every authorized SUDDUTH PEAR salesman carries a certificate of agency.

Prices-Prices herein given are subject to change without notice. Five will be furnished at 10 rate; fifty at 100 rate; 500 at 1,000 rates.

Claims-For shortage, damage in transportation, or otherwise we must be notified at once in order that same may be adjusted while details are fresh in mind.

Terms of Payment-Cash with order unless otherwise arranged. Remit by New York, Chicago or St. Louis draft; Postoffice or Express Money Order, made payable to Augustine \& Co., or by Registered Letter. Goods will be sent C.O.D. when one-half the amount is sent with the order.

Substituting-Should the supply of a variety be exhâusted (which will occasionally occur in all establishments, especially when the packing season is about over) it is our custom to substitute a sort, giving correct name, of equal or better value than the variety ordered, and when such is not in stock the number will be left unfilled and the money returned. It is mutually agreed, between ourselves and the purchaser, that when the words "No Substitution" are not written on the face of the order, permission to substitute is granted.

Packing-At the prices quoted no charge will be made for packing, baling or boxing, nor for delivery to the Carriers at freight depots or express offices.

Shipping-After delivering goods to the forwarders in perfect condition our control ceases, also our respnsibility. When explicit directions are not given as to route and manner in which goods are to be shipped we use our best judgment in selecting a route, but in no case can we be responsible for losses thereby. But all orders lost or 
spoiled in transit we refill free. The Illinois Central, Chicago \& Al. ton, Lake Erie \& Western,, and Big Four railroads, radiating as they do in ten different directions, and making direct connections with nearly every important trunk line in the country, afford the very best shipping facilities. Four pounds may be sent in a single package by mail. Small packages should be shipped by express. We can ship by express to all points, at 20 per cent reduction from the merchandise rate. The expense of shipping by express, on medium sized orders is seldom more than by freight and often less.

The Spring Packing Season-Begins about March 1, and continues through April and into May. The fall season begins about October 1, and continues until cold weather sets in. We can ship by express to Southern points any time during the winter months.

Shipping by Mail-We have had so many orders and inquiries for stock to be sent by mail that we make a special mailing price on all kinds of trees and plants that can be shipped by mail.

The new Parcel Post law does not apply to plants, except that we can now send eleven pounds instead of four as heretofore. The special rate in force in past years, one cent per two ounces or eight cents per pound is cheaper in most cases than the present Parcel Post rate.

Ordering-Order early by all means. There are many advantages to be gained by ordering early, besides the discounts. Nothing is to be gained by ordering late and then early orders find full stock. Please use order sheet. Write name plainly; give Post Office, County and State, be particular to state how the goods are to be shipped, whether by mail, freight or express, and give route. Keep a copy of the order and check off the trees, plants, etc., when they arrive.

\section{DISCOUNTS}

Allowed on all Orders Amounting to $\$ 5.00$ or Over.

8 per cent on orders placed during February.

5 per cent on orders placed during March.

Cash must accompany order for the full amount when discounts are allowed. The discount we allow is usually more than enough to pay the cost of freight, and saves us expense in bookkeeping.

\section{FREEDOM FROM DISEASE.}

Of Great Value to the Planter, is the fact that we have our nurseries and surrounding grounds examined each year by the department of Entomology at Champaign and a certificate of health accompanies every shipment we make. No San Jose scale or other injurious pest or disease has ever been discovered in our nurseries.

Yours very truly,

AUGUSTINE \& CO.,

Normal, Illinois. 


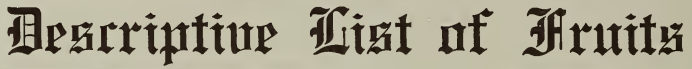

\section{*Apples}

\section{Price}

$\begin{array}{rlrrr} & & \text { Each } & 10 & 100 \\ \text { Mailing size, prepaid } \ldots \ldots \ldots \ldots \ldots \ldots \ldots \ldots & \$ 0.20 & \$ 1.80 & \$ 16.00 \\ 3 \text { to } 4 \text { feet, } 1 \text { or } 2 \text { years } \ldots \ldots \ldots \ldots \ldots & .20 & 1.50 & 11.00 \\ 4 \text { to } 5 \text { feet, } 2 \text { years } \ldots \ldots \ldots \ldots \ldots \ldots \ldots & .25 & 2.00 & 14.00 \\ 5 \text { to } 6 \text { feet, } 2 \text { and } 3 \text { years } \ldots \ldots \ldots \ldots & .30 & 2.50 & 20.00\end{array}$

Mailing size apple trees are strong, one year old trees, about 2 1-2 to 3 feet in height.

\section{APPLES-Summer.}

*Red Astrachan-Large, beautiful deep crimson. Sub-acid.

*Early Harvest-Medium, pale yellow, tender juicy.

*Duchess of Oldenburg-Good size, yellow, streaked red, juicy, rich, sub-acid, productive, one of the best.

*Yellow Transparent-Early white, tender, juicy, sprightly, sub-acid, medium size. Sometimes trees blight.

*Benoni-Medium, yellow, streaked with red, productive, juicy, rich

* Red June-Medium, early, an old favorite.

Rohes Favorite-A strong growing, handsome early summer apple. Flesh a little coarse, but good quality, and an excellent apple. A good new sort.

*Yellow Horse-Large, yellow, does exceptionally well in Southern Illinois and southern states, an excellent all purpose apple.

\section{Autumn}

*Maiden's Blush-Large, beautiful blush cheek, sub-acid.

*Fameuse (Snow)-Medium, deep crimson, flesh white, of best quality, hardy.

*Wealthy-Medium to large, red, sub-acid, hardy and productive, none better.

*Autumn Strawberry-Medium size, striped, highest quality, juicy, yields well.

*Fall Pippin-Large, somewhat oblong, good quality, keeps till December.

*Chenango Strawberry-Large, oblong, yellow, striped red, very handsome and high quality, productive.

\section{Winter}

Aiken's Red-Originated in the Northwest, an excellent apple of high quality, medium size, abundant yielder.

Arkansas Black-Large, dark red, strong grower, high quality.

*Ben Davis-Large, handsome, striped, valuable commercially, long keeper.

. Baldwin-Large, bright red, crisp, juicy, rich, adapted to the east.

Dominic-Similar to Rambo, but long keeper and better, flat, medium size, high quality, prodigious, early bearer, juicy.

* Gano, or Improved Ben Davis-Beautiful deep red, excellent.

*Grimes' Golden-Good size, yellow, of highest quality, very productive.

*Ingram-A seedling of the Janet, which it resembles somewhat, but larger, higher colored, and finer quality.

*Jonathan-Medium to large, red, highest quality, one of the best. Mann-A large greenish yellow apple that originated in Ill. Good quality, long keeper, hardy and free bearing.

"Recommended by the Illinois State Horticultural Society. 
*Minkler-Large, red, solid, productive, hardy, but a little slow to bear.

Milam-An old variety highly prized by some, medium, red, handsome, productive, good quality.

Mammoth Black Twig-Large, dark red, vigorous, good quality.

Northwest Greening-Large, hardy, yellow, long keeper.

Pewaukee-Large, mottled red, hardy, productive, good quality.

Rambo-Medium, good quality, greenish, an old variety.

Rawles Janet-Medium to small, long keeper, productive, good quality.

*Rome Beauty-Large, yellow, shaded red, sub-acid.

*Salome - An apple that is becoming very popular. Reddish stripes over greenish yellow body, very high quality, and for the North and Northwest especially valuable, on account of extreme hardiness and prolific bearing. Long keeper.

*Stayman's Winesap-Larger and an improvement on Winesap.

Stark-Large, striped light and red, juicy, mild sub-acid.

*Talman Sweet-Medium, yellow and red, rich.

*Walbridge Medium-Striped red, hardy, good quality.

*Wine Sap-Medium, dark red, crisp, sub-acid, an old standard.

*Willow Twig-Large, striped red, hardy, heavy yielder, extra long keeper, valuable commercially and for home use.

*York Imperial-Medium to large, flattened, yellow, shaded red, high quality.

\section{CRAB APPLES.}

\section{Price Same as Apples.}

*Transcendent-Productive, bright red, good. September.

Florence-Large, productive, becoming very popular. October.

Hyslop-Large, deep red, beautiful good. October-November.

Martha-One of the best, yellow, fine quality, enormous yielder.

\section{RUSSIAN APRICOTS}

\section{Price}

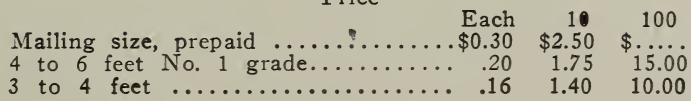

Alexander, Alexis and J. L. Budd-These are quite distinct from the European varieties, hardier, and will produce fruit when other apricots fail. They are all early bearers and productive.

\section{CHERRIES}

Compass-A hybrid of the cherry and plum, half cherry and half plum, hardy prolific and valuable, bears young.

This new fruit has attracted a great deal of attention and is becoming very popular. Trees are somewhat dwarfish in growth and quite ornamental, bearing enormous quantities of fruit. Also valuable in the far north where it is perfectly hardy.

\section{Prices}

Compass Cherry, 3 to 4 feet..... $\$ 0.30 \quad \$ 2.50 \quad \$ \ldots . .$.

- Recommended by the Illinois State Horticultural Soviety. 


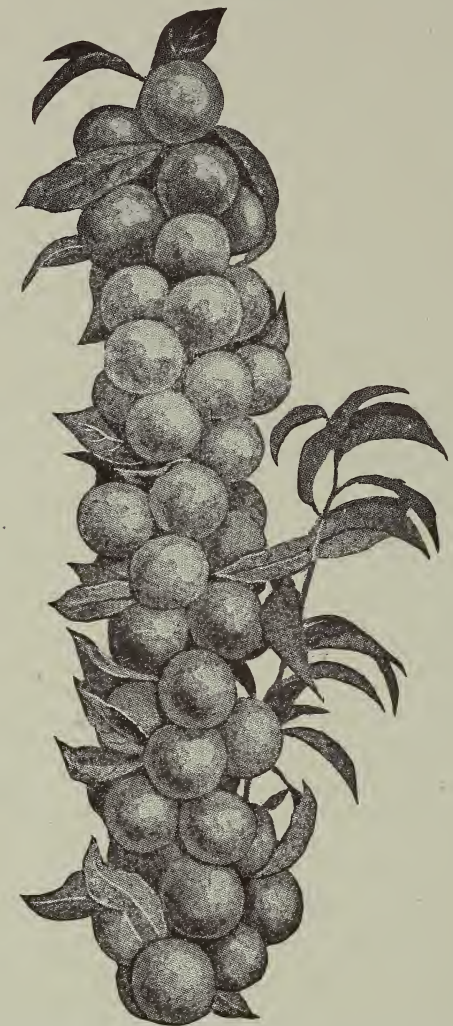

A BRANCH OF COMPASS CHERRY

$\begin{array}{lllrr}\text { Other Varieties } & \text { Each } & 10 & 100 \\ \text { Mailing size, prepaid } \ldots \ldots \ldots \ldots \ldots \ldots \ldots & \$ 0.30 & \$ 2.50 & \$ 20.00 \\ 5 \text { to } 6 \text { feet, stocky } \ldots \ldots \ldots \ldots \ldots \ldots \ldots & .30 & 2.50 & 20.00 \\ 4 \text { to } 5 \text { feet, stocky } \ldots \ldots \ldots \ldots \ldots \ldots \ldots & .25 & 2.00 & 18.00 \\ 3 \text { to } 4 \text { feet, branched } \ldots \ldots \ldots \ldots \ldots \ldots \ldots & .20 & 1.50 & 10.00\end{array}$

*Early Richmond-Medium size, dark red, juicy, rich, sub-acid. The old standard, nothing better. June.

May Duke-Large, early, dark red, delicious, not a sure bearer but a fine cherry, best of the Duke type.

*Montmorency, O.,-Larger than Ey Richmond, two weeks later, pro ductive and next best to Ey Richmond. June-July.

Northwest-A valuable new variety, ripens before Early Richmond, but hangs on later becoming almost black. Does not bear quite as well as Early Richmond.

Ostheim-Hardy, productive, large, dark red fruit, dwarfish growth, valuable, quite late. July-August.

\section{MULBERRIES}

Russian-A very hardy and strong grower, leaves suitable for feeding silk worms, fruit medium in size, varying from black to white, very sweet. The hardy Mulberry. If you want something new and up to date in an ornamental hedge, try the Russian Mulberry. Treat it just as you would privet.

Russian Weeping-See weeping trees.

${ }^{*}$ Recommended by the Illinois State Horticultural Society. 
Downing Everbearing-Very large fruit, black, sweet, rich, high quality.

\section{Prices}

Each $\quad 10 \quad 100$

Downing Everbearing, 4 to 6 feet....\$0.50 $\$ 4.00$

Russian, 5 to 7 feet ................ $30 \quad 2.50 \quad 21.00$

Russian, 4 to 5 feet ................ $.25 \quad 2.00 \quad 18.00$

Russian, mailing size, prepaid ...... $.15 \quad 1.25 \quad \ldots .$.

\section{PEACHES}

We make a specialty of growing peach trees in large quantities. We have a large stock of beautiful well-rooted trees, in perfect condition, of all the leading sorts. There is probably no one fruit that has given so much returns as the peach for the past five years in Central Illinois, some trees having produced from $\$ 5.00$ to $\$ 7.00$ worth of fruit per year. We shall be pleased to correspond with those desiring larger quantities than quoted.

\section{Prices}

\section{Special New Varieties}

Very valuable-See descriptions. Mailing size prepaid same price as 3 to 4 feet.

\begin{tabular}{|c|c|c|c|}
\hline & Each & 10 & 100 \\
\hline $\begin{array}{l}\text { Duaker, } 4 \text { to } 6 \text { feet } \\
\text { Ouaker } 3 \text { to } 4 \text { feet }\end{array}$ & . $\$ 0.40$ & $\$ 3.00$ & $\$ 20.00$ \\
\hline Sill, 4 to 6 feet ... & .50 & 4.00 & $\begin{array}{l}15.00 \\
30.00\end{array}$ \\
\hline ill, 3 to 4 feet & .45 & 3.50 & 25.00 \\
\hline flower, 4 to 6 & .40 & 3.00 & 20 \\
\hline yflower, 3 to 4 & .30 & 2.00 & 15.00 \\
\hline
\end{tabular}

\section{Standard Varieties.}

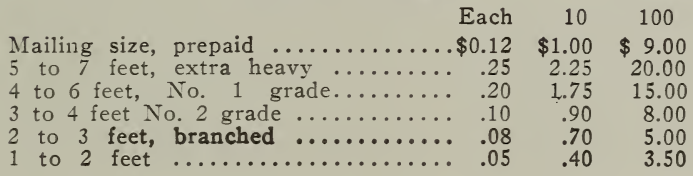

\section{SPECIAL NEW VARIETIES}

Sill-This new peach originated here at Normal and is a cross between Elberta and Mixon. The tree is an ideal commercial grower, being stocky, and vigorous, and very large dark green leaves.

The fruit in appearance resembles Elberta, averaging nine inches in circumference, with a little more red and a higher color generally, very large and remarkably uniform size and perfect fruit. A perfect free stone. In quality the Sill is superior to Elberta, the flesh is more solid, finer grained and a better keeper. Ripening a week to ten days after Elberta.

On September 3, we sent samples of the Sill to J. H. Hale, of South Glastonbury, Conn., the best authority and largest grower of peaches in the United States. October 10, he wrote "Yours of October 3 and the seedling peach came promptly by mail. I tested two of them and found them of fine texture and of about the same quality as Elberta. The other two specimens I left on top of my desk through the entire month of September, and they were still sound at the end of the month, although greatly shriveled. On the 9th of October I threw them away and they were perfectly sound. This would indicate it has good keeping qualities. I shall now watch my tree here with great interest."

After watching and testing the Sill peach for the past seven years, we believe it is destined to become one of the great commercial peaches of this country. The Horticulturists who have been watching the Sill for the past few years pronounced it beyond question the most promising peach ever grown in Central Illinois. The demand for the Sill has been very heavy but we hope to be able to fill all orders this year.

* Recommended by the Illinois State Horticultural Society. 


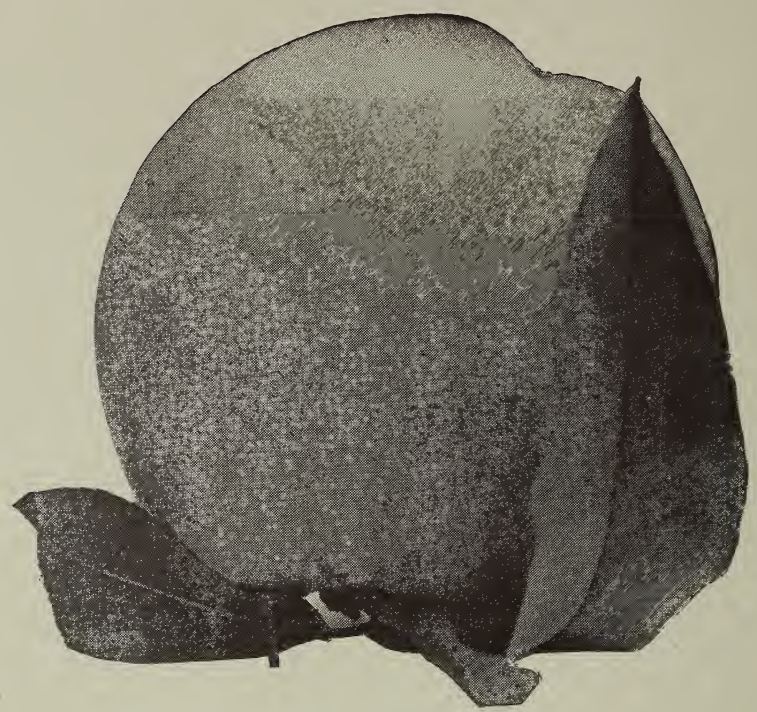

SILL PEACH

Quaker-Some ten years ago, Col. Milton L. Haney, of this place, while visiting in the northwest portion of Iowa, had his attention attracted to a remarkably hardy peach seedling growing in a Quaker settlement, this variety being the only one that would stand the extreme cold of that section. He brought us some buds from which we grew a few trees. These we tested and placed in a number of places and have grown the Quaker here at Normal. The Quaker has stood the test of hardiness, having borne several years when every other peach bud in this section was killed. The fruit is not as large as some, but large enough for every purpose, and of very good quality. The trees usually set too much fruit and for best results should be severely thinned. Where hardiness in tree and bud is of principal value, we recommend it very highly.

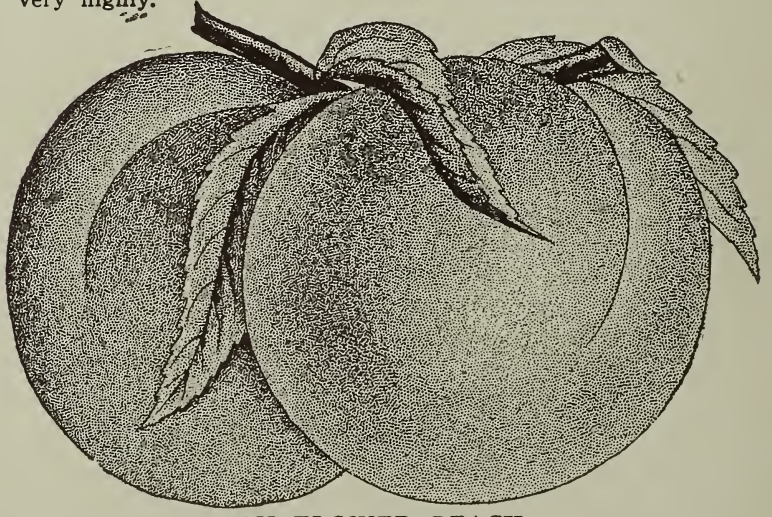

MAY FLOWER PEACH

Mayflower-This new Peach is claimed to be the earliest ripening peach ever introduced. Is yellow fleshed, with beautiful red *Recommended by the Illinois State Horticultural Society. 
cheek, and excellent quality, being a much better keeper and shipper than other early sorts. Although we have not yet fruited the Mayflower, we feel safe in recommending it on account of the strong endorsements it has received.

\section{STANDARD VARIETIES}

*Alexander-Medium, greenish white, nearly covered with beautiful red, sweet, juicy, rich, early. July.

Admiral Dewey-New, medium to large, one of the earliest, hardy and productive, highly recommended. July.

*Beer's Smock-Large, yellow flesh, prolific, a good commercial sort, last of September.

Bokara-Very hardy, abundant bearer, medium size, fair quality, middle of September.

Belle-(Belle of Georgia)-Very large, skin white with red cheek; flesh white firm and of excellent flavor. Tree a rapid grower, very prolific, fine shipper. Ripens with Crawford's Early.

*Champion-A large, handsome early variety, creamy white with red cheek, sweet, rich and juicy. Hardy and productive. The best and hardiest white peach. August.

*Crawfords Early-A magnificent large yellow peach of good quality. Early in September.

Crawford's Late-A superb, large yellow peach. One of the best. Last September.

*Carman-Large, resembles Elberta in shape; color creamy, white or pale yellow with deep blush; skin very tough, flesh tender, fine flavor and quite juicy; one of the hardiest. Ripens two or three weeks before Elberta. The best of its season.

Engle's Mammoth-Large, yellow; resembles late Crawford. More productive. September.

*Elberta-Large, yellow, with red cheek; flesh yellow, firm, juicy. Ex. ceedingly prolific, sure bearer and hardy. The leading market variety. Follows Early Crawford.

Emma-Similar to Elberta but two weeks later.

* Foster-Large, deep orange red, flesh yellow; very rich and juicy. Last of August.

Fitzgerald-An improved Ey. Crawford equaling it in size, quality and color, hardy, large bright yellow with red cheek. AugustSeptember.

*Greensboro-The largest and most beautifully colored of all the early varieties. Double the size of Alexander, ripening a few days later. Flesh white juicy, and good. July.

Gen. Lee-A cling of good size and quality, fine for preserving. September.

Hill's Chili-Medium dull yellow. Extra hardy and productive. Last September.

*Heath Cling-Very large, flesh white, juicy and melting. Good keep. er and shipper. The best white flesh cling. October.

*Lemon Cling-Large, yellow, lemon shape, red cheek. September.

*Mountain Rose-Large, red, flesh white, juicy, hardy and one of the best. August.

*Old Mixon Free-Large, pale yellow, deep red cheek, flesh white, tender and rich. September.

Smock-One of the old standard yellow peaches, delicious quality and excellent in every way. A little later than Elberta.

Sneed-The earliest, medium size, cling, white and red cheek. Rots in some seasons but valuable on account of earliness.

*Stump the World-Medium to large, white flesh with a bright red cheek. Same season as Elberta.

Triumph-Ripens with Alexander, a few days after Sneed. The earliest yellow flesh peach, good size, handsome and fair quality, vigorous grower.

Waddell-Medium size to large, hardy and abundant bearer, flesh white, with red cheek, a good shipper for an early variety, ripens with Carmen.

\footnotetext{
* Recommended by the Illinois State Horticultural Society.
} 


\section{* Sudduth Pear}

THE SUDDUTH PEAR TOOK FIRST PREMIUM FOR PEARS AT THE LA CROSSE INTER-STATE FAIR OF WISCONSIN FOR 1911 AND AGAIN IN 1912.

The Original Sudduth Pear Tree is now 92 years old and although every one of the original limbs has been broken off by heavy loads of fruit and storms of late years, yet it promises to round out a century of most remarkable history.

Nearly a hundred years and never failed a single season to bear a good crop of fruit, often as high as eighty bushels.

Never a blighted branch.

As hardy as an Oak, and, until broken, as handsome in form and foliage as a Sugar Maple.

The trunk of the tree is more than 10 feet in circumference, and looks as clean and healthy as a ten year old tree.

The fruit is classed as medium in size, excellent in quality, and ripens from the middle to the latter part of October.

The fruit is almost seedless, unless the blossoms are highly fertilized by other varieties of pear near by. There is no woody or gritty substance in the core but meat all the way through with no tough covering of the seeds, hence it is an excellent dessert fruit and without question the most valuable canning or preserving pear known, the peculiar formation of the fruit making it as easy to peel by machinery as an apple, with no core to remove.

The seed of the original Sudduth Pear Tree was brought from Xenia, Ohio, by Thos. Constant when he came west to Illinois, and was planted in the spring of 1820 , before grafted fruits could be obtained. This seed was planted on Thos. Constant's farm that he entered from the Government, a year previous to the time Illinois was admitted to the Union as a State. Sixty-five years ago 9 grafts were made of the Sudduth, and planted on nearby farms, and later other grafts were made and planted. These grafts, as well as the younger trees propagated of late years, have all the characteristics of the original Sudduth Pear Tree; in growth, hardiness, and fruits, as well as the habit of annual bearing and the entire freedom from blight and disease.

We first had our attention called to the Sudduth Pear about 20 years ago by Mr. Titus Sudduth, who owned the farm on which the original tree stood, having purchased it from Judge Logan, Abraham Lincoln's law partner, in 1862. Mr. Sudduth had known the tree since 1835 , and fearing that something would happen to destroy the tree got us to make some grafts from it.

The beautiful growth, hardiness and early bearing of these grafts was what first opened our eyes to its value. We then went down to Williamsville, Sangamon Co., Illinois, to see the tree, and talked with all the old settlers in that vicinity, and came to the only conclusion possible, that The Sudduth Pear, though up to that time overlooked, was undoubtedly the most valuable and wonderful variety of fruit we had ever known. We immediately took steps to control all the wood of the then existing trees with the intention of propagating it, and determined to have the name trademarked and registered.

* Recommended by the Illinois State Horticultural Society. 
also to send out each tree with this registered trademark in the form of a lead seal attached to every tree sold. This was done to protect the public from unscrupulous tree men, who, we know would soon sell Sudduth Pear without authority, and attempt to substitute an inferior or cheaper tree.

Send for our 34-page illussrated History of the Sudduth Pear, the most interesting history of any fruit ever introduced. Free, for the asking.

None genuine without our lead seal attached by a copper wire.

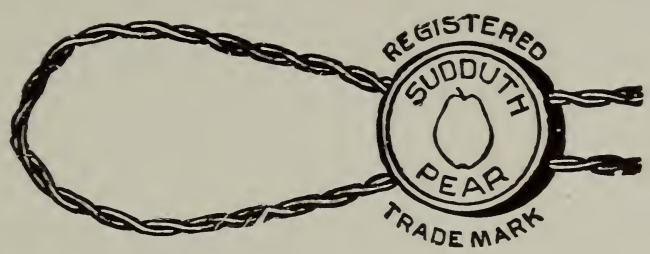

WHY THE SUDDUTH PEAR HAS BECOME FAMOUS

The Sudduth Pear has been highly indorsed by more prominent fruit men than any new fruit ever introduced.

A number of pears called blight proof have come, are gone and forgotten, but the Sudduth Pear has withstood the blight for nearly 2 century.

As handsome in form as a hard maple.

Hardy in the far north.

Does well in the south.

Attains great size.

Very long lived.

Bears abundantly.

Bears annually.

Fruit of highest quality.

The greatest canning pear known.

The Sudduth Pear has a History that is a History, extending over a period of ninety years, free for the asking.

\section{Price of Sudduth Pear.}

Five to seven feet, first-class trees.

$\$ 1.50$ for a single tree; $\$ 6.00$ for five; $\$ 1.00$ each for ten or more trees. Mailing size, prepaid, same price.

\section{OTHER VARIETIES OF PEARS.}

*Bartlett-Large, buttery, juicy and high flavored, very popular where blight is not too bad. August and September.

*Flemish Beauty-Large, juicy and rich, hardy and moderately free from blight. September-October.

*Garber-A Japanese Hybrid, earlier and larger than Keiffer, and of better quality, though not as long a keeper. Plant with Keiffer as a fertilizer. Quite free from blight.

* Keiffer-Large size and handsome, with remarkable keeping qualities, though not of the highest quality is excellent for culinary purposes, and one of the most profitable and sure bearers. Plant either Garber, Mikado or Duchess Dwarf with it for fertilizer. Quite free from blight. September to January.

*Sheldon-Medium size, yellow with red cheek, a splendid pear though a little coarse and reasonably free from blight, hardy and abundant bearer.

*Seckle-A small russet pear of the highest quality. SeptemberOctober.

* Recommended by the Illinois State Horticultural Society. 
*Lincoln-Introduced by us twenty years ago, originated at Lincoln, Illinois. For many years we sent it out under our seal. A large yellow, sweet, juicy pear of high quality, resembling Bart. lett but not as subject to blight and of higher quality. We received a bronze medal for Lincoln pears at the Buffalo Exposition.

\section{Prices}

Each $\quad 10 \quad 100$

Mailing size, prepaid $\ldots \ldots \ldots \ldots \ldots \ldots \$ 0.25 \quad \$ 2.00 \quad \$ 16.00$

5 to 7 feet $\ldots \ldots \ldots \ldots \ldots \ldots \ldots \ldots \ldots \ldots .35 \quad 3.00 \quad 25.00$

4 to 6 feet $\ldots \ldots \ldots \ldots \ldots \ldots \ldots \ldots \ldots .30 \quad 2.50 \quad 22.00$

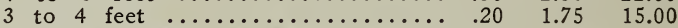

Lincoln Pears, 5 cents per tree more than above prices.

\section{DWARF PEARS}

*Duchess-(Angouleme) very large, rich, juicy, excellent. The best dwarf pear grown. October.

Price: 4 to 5 feet $\ldots \ldots \ldots \ldots \ldots \ldots \$ 0.30 \$ 2.50 \$ 20.00$

\section{PLUMS}

Wilson-The Wilson plum came to us among a lot of seedlings from Iowa about 15 years ago, and was planted in our experimental orchard. It came into bearing quite early and from the first attracted attention on account of the superior quality of the fruit.

The fruit is very large for a native sort, flesh solid and meaty, quality rich, sweet, with no bitter taste to skin. Color a bright red, with a touch of yellow on lower side, form slightly oval and ripens a little after the Wild Goose.

As we further tested the Wilson we found that it was not only a superior fruit but a very heavy bearer and in the eleven years we have fruited it, we have gotten nine good crops, one slight crop and one failure, caused by a heavy freeze in May that killed all the fruit in the orchard.

We have gotten from the Wilson at least 4 bushels of fruit to one of any other variety.

While every variety tested has been seriously affected with both Curculio and Rot, we have never found a wormy plum in the Wilson, nor has the fruit ever been attacked by the Rot.

So far as this section of the country is concerned, at least, we unhesitatingly place the Wilson at the top of the list, both for home use and commercial purposes.

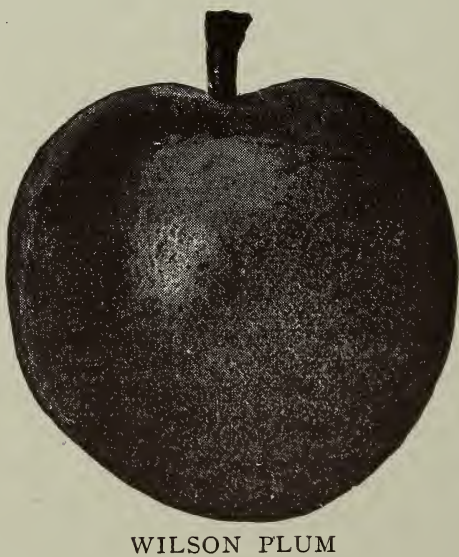

* Recommended by the Illinois State Horticultural Society. 


\section{Prices}

\section{Wilson}

\begin{tabular}{|c|c|c|}
\hline & Each & 10 \\
\hline $\begin{array}{l}\text { g size, prepaid } \\
\text { feet } \ldots . . . . . . .\end{array}$ & & $\begin{array}{r}\$ 6.00 \\
6.00\end{array}$ \\
\hline
\end{tabular}

Japan, Native and European.

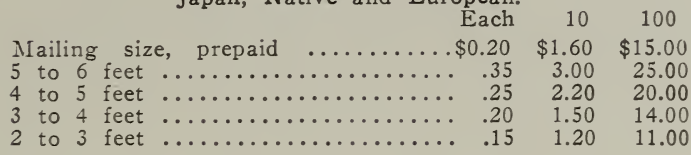

The Three Best Japanese Varieties

*Abundance-One of the best known Japanese varieties, hardy and productive, fruit large, yellow, overlaid with red. Good. August.

*Burbank-Another Japanese variety, ripening two weeks after. Abundance, larger and heavy bearer, ships well, tree sprawling, vigorous grower, good, August.

* Red June-The best Japanese plum to ripen before Abundance, medium size, cherry red, good quality, heavy bearer, one of the best and most profitable, very free from rot.

\section{Improved Native Plums.}

*De Soto-Medium, bright red, very hardy, an abundant and sure yielder, profitable. September.

America-A new hardy native plum, red, of large size and good quality. September.

* Miner-An old standard native plum, large, juicy, sweet, reddish cast with yellow dots, a splendid plum, sometimes overlooked for newer varieties not nearly so good. September.

*Wolf-Large, free stone, fine as a dessert fruit, very popular and hardy. August.

*Wild Goose-Fruit medium to large, dark red, and a standard commercial sort, sure bearer and excellent quality. July.

Milton-Similar to Wild Goose, larger, very hardy and a splendid variety, originated in Iowa, earlier than Wild Goose.

Chas. Downing-Another Iowa plum that has done splendidly, red and yellow, of excellent quality. Three weeks later than Milton.

\section{European Plums.}

*Damson-Small blue plums that are enormous yielders and much sought after for canning and preserving. September.

Lombard-A well known large blue plum, very hardy and abundant bearer, quality good. September.

*Shipper's Pride-Resembles Lombard in color and quality, is much esteemed on account of its market qualities.

\section{QUINCE}

* Champion-A prolific and heavy bearer, more oval in shape than Orange, long keeper, quality fine, late.

*Orange (Apple)-Fruit large, bright yellow, excellent flavor.

Meech's Prolific-Strong grower, very productive, fruit large, orange color and very fragrant. Excellent.

Rea-A seedling of the Orange of same color and shape but larger.

\section{Prices}

3 to 5 feet, well branched $\ldots \ldots \ldots \ldots \ldots \ldots \$ 0.40 \quad 3.25$

* Recommended by the Illinois State Horticultural Society. 


\section{BLACKBERRIES}

*Snyder-The hardiest and best all purpose blackberry. We introduced it to the west over thirty years ago and it still holds its place at the top of the list for hardiness, yield and quality.

*Ey. Harvest-Very valuable where it is not too cold, needs protection in the north. Two weeks earlier than Snyder and fruit not quite so large. Solid and a good shipper.

La Grange-A new hardy blackberry, said to be of Russian origin, a vigorous grower, canes measuring 12 to 14 feet if not trimmed. Later and larger than Snyder, and a heavy yielder, remarkably free from rust and disease, highly recommended and a very promising new berry. Stock limited.

Prices

By mail prepaid add $2 \mathrm{c}$ extra per plant.

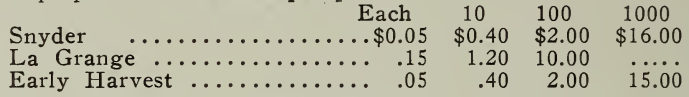

\section{DEWBERRIES}

Lucretia-A low growing or trailing blackberry, larger and juicier than blackberries, perfectly hardy, fruit ripens ten days before blackberries and is often one and a half inches long and one inch in diameter. Mulch to keep berries off the ground; an enormous yielder, and no fruit garden is complete without them.

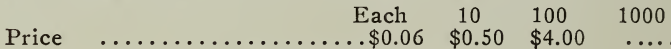

\section{RASPBERRIES}

*Columbian, (Purple)-This variety has given the best results of its class here, fruit purplish red, enormous size berries, and strong. est g:")wing canes of any variety. A wonderful producer.

* Cumberland (Black) - Fruit is larger than any other black cap, qual. ity excellent, a firm berry, jet black, splendid shipper, very desirable for market or home use, being very vigorous and productive.

*Gregg (Black)-A well known standard commercial sort, fruit very large, solid, enormous yielder, a very reliable sort.

* Kansas (Black) - A well known standard sort, much used by commercial growers, an enormous producer, fruit large and high quality. None better.

* Cuthbert (Red)-Undoubtedly the best of the reds, strong grower, fruit large, firm, high quality and very prolific, extensively planted for home use and market.

Plum Farmer, (Black) - Of recent introduction, and one of the most promising berries ever introduced. Fruit borne in great abundance, large, excellent quality.

ST. REGIS, EVERBEARING (Red)-The latest thing in raspberries. Although we have not had it long enough to venture a positive opinion this new berry is claimed to be a most wonderful berry, being a true everbearer, yielding throughout the summer an abundance of fruit, of the highest quality. Is reasonably ever-bearing with us and heavy yielder. Our customers speak very highly of St. Regis and it is certain to become very popular. Our stock is genuine, from the originator.

Prices

By mail, prepaid, 2c extra per plant.

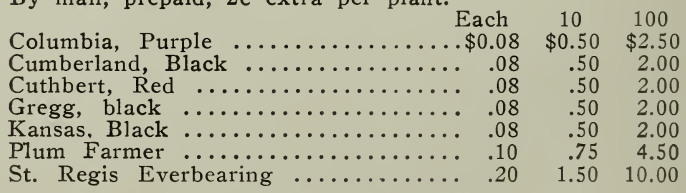

JUNE BERRIES-Dwarf.

Service, or Shadberry-These valuable garden berries are being used more and more, very similar to blue or huckle berries, borne in profusion, very fine for serving fresh or canning. Succeed everywhere.

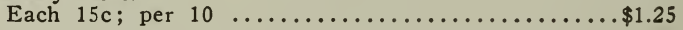

*Recommended by the Illinois State Horticultural Society. 


\section{CURRANTS}

One of the easiest to grow and one of the most valuable fruits of the garden.

*Perfection-A new variety, recently introduced, and well named, Perfection. Hardy, abundant bearer, highest quality, fruit as larg or larger than Fay's. Pronounced by experimental stations and leading horticulturists everywhere, the finest red currant ever introduced. Has taken more inedals and awards than any other currant.

Black Naples-A very strong, vigorous grower, probably the best of the black currants, prolific and large fruit.

*Cherry-Well named, berries very large, bunches short, plant vigorous and productive, a standard and hard to beat.

* Red Dutch-An old variety and still very popular, and though not as large as some, the quality and yield make up for that, hardy, vigorous, excellent.

London Market-A bright red currant, long bunches, good size, and a splendid currant. Much used for commercial planting.

Fay's Prolific-One of the largest currants grown. Bunches medium length, quality very fine, an excellent market sort.

*Red Cross-With us the Red Cross has thus far proven superior to every other variety except Perfection in yield, size, quality and hardiness, as well as vigor of growth. You will make no mistake in planting the Red Cross.

*White Grape-A very large golden white currant, sweet, fine flavor, fine for table use, very thrifty and vigorous, the best white currant.

\section{Prices}

By mail, prepaid, 2c extra per plant.

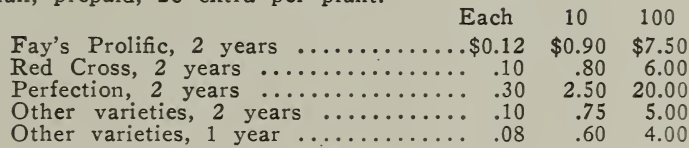

\section{GOOSEBERRIES}

One of the most valuable commercial fruits grown.

*Downing-A native variety, large, pale green, handsome, and fine quality, free from mildew, bush a vigorous grower and heavy yielder.

*Houghton-Smaller than Downing, pale red when ripe, of highest quality, and an enormous yielder, free from mildew, one of the best. Will yield more fruit to the plant than any other variety, excellent for canning.

Industry-Plants imported, a very large berry, excellent flavor and less subject to mildew than most foreign varieties.

\section{Prices}

By mail, prepaid, 2c extra per plant.

\section{Each $10 \quad 100$}

Houghton, 2 years $\ldots \ldots \ldots \ldots \ldots \ldots \ldots \ldots \ldots . \$ \ldots .12 \$ 1.10 \$ 10.00$

Downing, 2 years $\ldots \ldots \ldots \ldots \ldots \ldots \ldots \ldots \ldots \ldots \ldots .12 \quad \begin{aligned} & \$ 1 \\ & 1.10\end{aligned} 10.00$

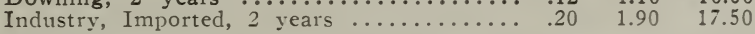

${ }^{*}$ Recommended by the Illinois State Horticultural Society. 


\section{GRAPES}

There is scarcely a yard so small, either in country or city, that room for one to a dozen or more grapevines cannot be found. They do admirably trained up to the side of any building, or along the garden fences, occupying but little room and furnishing an abundance of the healthiest of fruit. Make the soil mellow, and plant the vines somewhat deeper than they stood in the nursery. Plant about 8 feet apart, by the fence or building. For vineyards, make rows 8 feet apart, 6 to 10 feet in rows.

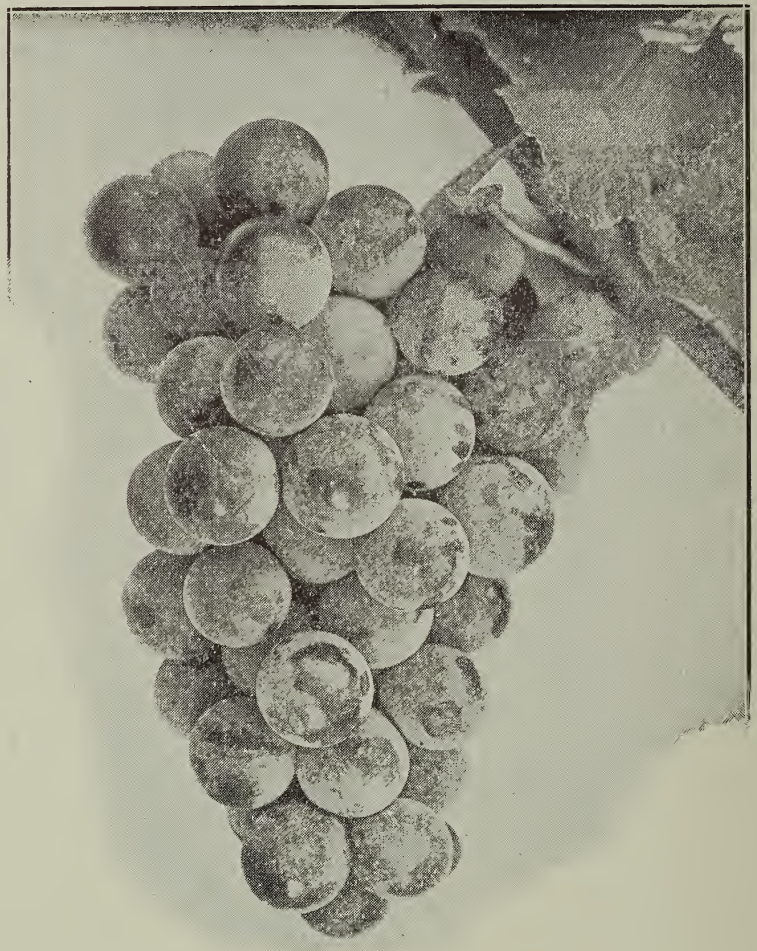

MOORE'S EARLY GRAPE

By mail, prepaid, 2c extra per plant.

Strong, 2 year Plants.

\begin{tabular}{|c|c|c|c|}
\hline & Each & 10 & 100 \\
\hline righton, Red &.$\$ 0.15$ & $\$ 1.25$ & $\$ 9.00$ \\
\hline ord, Black & .08 & .70 & \\
\hline aware, & .10 & .90 & 8.00 \\
\hline ethe, Pink & .25 & 1.85 & 16.00 \\
\hline len Pockling & .12 & 1.00 & 8.00 \\
\hline Black & .10 & .80 & 7.00 \\
\hline ore's Diamond & .10 & .80 & 7.00 \\
\hline ore's, Early, Black & .12 & 1.00 & 8.00 \\
\hline gara, White & .1c & .80 & 7.00 \\
\hline orden, Black & .12 & 1.00 & 8.00 \\
\hline oodruff, Large, $\operatorname{Re}$ & & 1.75 & 15.00 \\
\hline
\end{tabular}

${ }^{*}$ Recommended by the Illinois State Horticultural Society. 


\section{Black.}

* Concord-The well known standard variety, succeeds wherever grapes will grow.

* Moore's Early-Bunch large, berry large round, with heavy bloom, vine exceedingly hardy. Its earliness makes it desirable for an early market. Its hardiness particularly adapts it to Canada and northern portions of the United States; succeeds admirably in the south. The early grape.

*Worden-A splendid grape of the Concord type, large, better quality and earlier. Vine vigorous; hardy and productive.

*Ives-Bunch long, compact, medium size berry and bunch, hardy, abundant yielder, quality medium, a little foxy, excellent for culinary purposes.

Red or Amber.

*Brighton-Bunch large, well formed; berries above medium to large round; excellent flavor and quality; one of the earliest in ripening.

Delaware-Bunches small, compact, shouldered; berries rather small, round; skin thin, light red; flesh very juicy, sweet, spicy and delicious.

*Woodruff-A handsome, profitable sort; vine vigorous, productive; iron-clad constitution. Bunch and berry large, attractive; ripens early; fair quality, long keeper, good shipper.

White.

*Goethe-Greenish yellow, red tinge, berry large, bunch medium, abundant, excellent flavor, tender and sweet; an excellent hardy grape.

* Moore's Diamond-A leading early white grape, ripening before Moore's Early. White, with rich yellow tinge; juicy, few seeds, almost free from pulp, excellent quality; above medium size, adheres freely to stem. Vine like Concord in growth, hardiness and foliage. Fine variety for both market and home garden.

*Golden Pocklington-Bunch and berries large, when fully ripe a light golden yellow; juicy, tender, sweet, with little pulp. Vine thoroughly hardy, strong grower, free from mildew; productive. One of the most satisfactory white varieties.

* Niagara-This white grape is justly regarded as one of the very best known; very fine quality for a table grape; very prolific, hardy and of fine flavor. Fruit keeps well, if carefully handled; one of our favorite sorts.

\section{STRAWBERRIES}

Strawberries will succeed in any soil that is suited to ordinary garden or farm crops. There is nothing that will give more returns or greater enjoyment for a little trouble than strawberries, and every family can have a good supply all through the season at less expense than buying a few poor berries now and then at the market.

Varieties marked (P.) have an imperfect blossom and must have a variety not so marked planted by them for fertilizer.

*3-W. - This is a chance seedling strawberry found growing along the railroad a few years ago. We have fruited the 3-W for three years on our grounds, and it has been tested by many of the leading berry growers in this and adjoining states. The berries are very large and uniform in shape, it has a perfect blos. som, needing no other berry for fertilizer. It is a rich red all the way through, very solid, holding up well and making an excellent shipper. Quality excellent, and sweet.

Commence to bear early, and continues clear through the season, holding up well in size and quality. The $3 \cdot \mathrm{W}$ is one of the heaviest yielders we have ever seen, setting enormous crops that ripen up perfectly.

The 3.W took the silver medal at the St. Louis Exposition after having been shipped 500 miles and were on the exhibition tables for 10 days, as hard a test as could have been given. One plant has given as much as a quart of berries at a picking. The plants are the strongest growers, with the largest roots we have ever seen, with heavy long fruit stems nearly as large as a

* Recommended by the Illinois State Horticultural Society. 
lead pencil. The $3-\mathrm{W}$ is highly endorsed by the Illinois Experiment stations, in some instances for exceeding all other varieties.

*Brandywine-A fine, large, late, handsome, productive berry of excellent quality, regular, conical form; dark glossy red, extending to the center. Plant healthy and vigorous, abundant producer. An extra good sort for all purposes.

*Gandy-A reliable late variety, berries bright crimson, very uniform in size and shape, large and firm, plants vigorous and healthy.

*Senator Dunlap-A well tested, wonderfully productive variety, one of the safe sort to plant everywhere. Has taken a high place among the prominent standard sorts. Plant resembles Warfield, rampant runner, should be restricted in its production of plants; fully equal to Crescent and Warfield in its ability to succeed under all circumstances. Fruit good size, regular form, beautiful bright red, glossy, firm, splendid keeper and shipper, excellent quality, one of the best for canning. Ripens early and continues a long time. It stands at the head in its wonderful ability to ripen a good crop under almost any condition of doubt or neglect. The best.

*Warfield (P) - Its great beauty, firmness, earliness, good flavor, productiveness and vigor make it exceedingly popular. Ripens with Crescent, and is superseding that variety for a reliable market sort.

Strawberries must be shipped either by express or mail.

Price

$\begin{array}{lll}10 & 100 & 1000\end{array}$

3-W, special $\ldots \ldots \ldots \ldots \ldots \ldots \ldots \ldots \ldots+50 \quad \$ 1.75 \$ 15.00$

Other vatieties $\ldots \ldots \ldots \ldots \ldots \ldots \ldots \ldots \ldots . .15 \quad .75 \quad 6.00$

By mail prepaid add ............... .05 .25

\section{GARDEN ROOTS}

\section{ASPARAGUS}

Conover's Colossal-The standard variety used by market gardeners everywhere. We have grown five different varieties, and all the difference that could be dectected was in the name. Under like treatment they are identical.

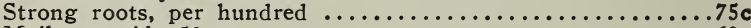

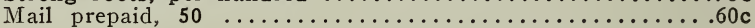

\section{RHUBARB OR PIE PLANT}

Linnaeus and Victoria-Both excellent standard sorts, should be in every garden.

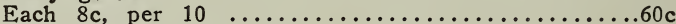

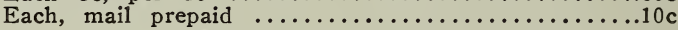

\section{HORSE RADISH}

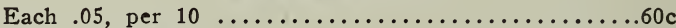

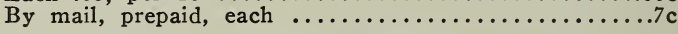

\section{NUT TREES}

*Japanese Walnuts-From Japan, of great value. Trees make beautiful shade trees and commence bearing quite young, good crops of delicious nuts, resemble butter nuts in size and shape, but with thinner shells; perfectly hardy and desirable. Certain to become one of our popular trees.

Almonds-Hard Shell-A very ornamental tree and bears plump rich nuts. Will do well wherever the peach does well. The shell is harder than the soft shell but quality just as good. Valuable.

Soft Shell-Not quite so hardy as hard shell.

\section{Price}

Almonds, hard shell or soft shell, 4 to Each $10 \quad 100$

6 feet $\ldots \ldots \ldots \ldots \ldots \ldots \ldots \ldots \ldots \ldots 0.35 \$ 3.00 \quad \ldots \ldots$

Walnuts, Japan, 2 to 3 feet $\ldots \ldots \ldots . .25 \quad 2.25 \quad 20.00$

${ }^{*}$ Recommended by the Illinois State Horticultural Society. 


\section{PERSIMMONS}

The American Persimmon is hardy in Central Illinois. The top may kill back a little while young, but they make handsome trees as they grow older, yielding quantities of delicious fruit. Well worth planting.

\section{Price}

4 to 5 feet, each $35 \mathrm{cts}$, per $10 \ldots \ldots \ldots \ldots \ldots \ldots .00$

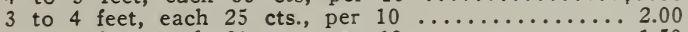

2 to 3 feet, each 20 cts., per $10 \ldots \ldots \ldots \ldots \ldots \ldots . . . \ldots$

\section{Flowering Shrubs}

No lawn or yard, whether large or small is either complete, attractive or homelike without a certain amount of flowering shrubs.

Properly arranged they in no way encroach upon the lawn. They not only add beauty and adornment but at the same time can be used as screens to cover unsightly objects or fences, and break the founda. tion line of the house. They are indispensable, besides lending a cheerful homelike effect. A few dollars spent in shrubs will often add more value to a property than hundreds of dollars spent in other ways.

Following each name is the height the variety attains, together with time of blossoming.

ALTHAEA, OR ROSE OF SHARON, (Hibiscus Syriacus)

Seven to Ten Feet. August to October

One of the most valuable late summer blooming shrubs. We have the finest budded sorts in both double and single flowers, named varieties. Colors white, blue, rose red, and purple.

\section{Price}

2 to 3 feet, each $20 \mathrm{c}$, per 10

\section{BARBERRY (Berberis)}

The Barberries compose some of our most valuable shrubs. They are not only beautiful for foliage and flower, but the bright red fruit remaining throughout the winter adds another rare charm. They are valuable for informal hedge but should not be trim. med.

Red Fruited, (Vulgaris) 5 to 6 feet-Foliage bright green, yellow blossoms in May, densely covered with red fruit, hanging on till late winter.

Purple Leaved, (Vulgaris, Atropurpurea)-Five feet-Similar to the red fruited except purple foliage. The blossoms in early May, with purple back ground of leaves, are as handsome as any plant of its season.

*Thunberg's or Japanese, (Thunbergii)-Four feet-The finest of all the Barberries, grows in compact form, sriney stems, foliage fine and dense, changing to brilliant red in iall, the clusters of red berries hanging on all winter. Much used for hedge and borders. Considered by many to be the most valuable shrub grown. Not only because of its beauty, but is also adapted to so many uses and perfect hardiness.

\section{Price}

Red Fruited and Purple Leaved.

12 to 18 inches, each $15 \mathrm{c}$; per $10 \ldots \ldots \ldots \ldots \ldots \ldots . . .00$

18 to 24 inches, each $20 c$; per $10 \ldots \ldots \ldots \ldots \ldots \ldots . . .6 \ldots$

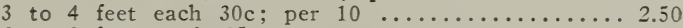

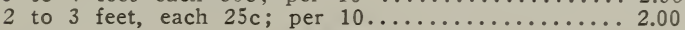

\section{Japanese.}

6 to 12 inches, each $10 \mathrm{c}$; per $10 \ldots \ldots \ldots \ldots . . \ldots 5$

12 to 18 inches, each $15 \mathrm{c}$; per $10 \ldots \ldots \ldots \ldots \ldots \ldots \ldots \ldots \ldots \ldots \ldots \ldots \ldots \ldots .25$

18 to 24 inches, bushy, each $25 \mathrm{c}$; per $10 \ldots \ldots \ldots 2.00$

\section{BUCK THORN-Rhamnus.}

Catharticus, a fine vigorous shrub with excellent dark green foliage, white blossoms followed by small black berries. One of the very best hardy hedge plants. Hedges of 50 years are still in fine condition here at Normal. Stands severe pruning.

* Recommended by the Illinois State IIorticultural Society. 
Price.

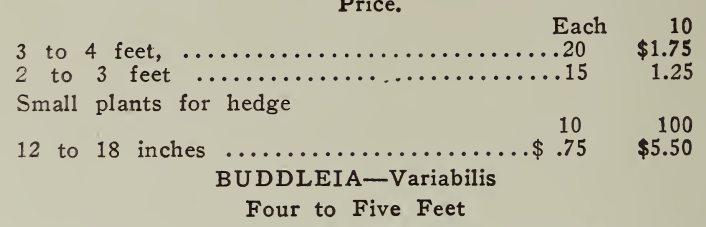

A most charming summer flowering shrub, but little known. The branches are sometimes injured by the winter, but it makes a strong growth, blooming the same year; blossoms in long spikes, delicate lilac. August and September.

\section{Price}

Each 10

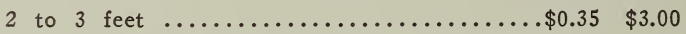

\section{CORALBERRY, See Snowberry}

*CRANBERRY, (High bush.)-See Snowball CURRANT-Flowering (Ribes Aureum)

\section{Six Feet}

The golden flowering currant, blooms in April and May, followed by large black berries, fragrant and showy, thrives everywhere, in any soil, red leaves in autumn. An excellent shrub for massing in background in poor soil.

\section{Price}

18 to 24 inches, each $15 \mathrm{c}$; per $10 \ldots \ldots \ldots \ldots \ldots \ldots \ldots \ldots \ldots \ldots \ldots \ldots$

2 to 3 feet, each $20 \mathrm{c}$; per $10 \ldots \ldots \ldots \ldots \ldots \ldots 1.75$

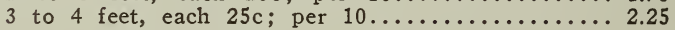

\section{CALYCANTHUS, Floridus (Spice Bush)}

\section{Six Feet.}

Sweet scented shrub, wood and flowers have a delightful fragrance, blooms in profusion, flowers size of double tuberose, dark brown or purple. May. A refined and choice shrub.

\begin{tabular}{|c|c|c|c|}
\hline \multicolumn{4}{|c|}{ Price } \\
\hline & & Each & 10 \\
\hline $\begin{array}{l}12 \text { to } 18 \text { inches } \\
18 \text { to } 24 \text { inches } \\
2 \text { to } 3 \text { feet .... }\end{array}$ & 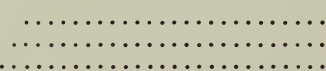 & $\begin{array}{l}.25 \\
.30 \\
.35\end{array}$ & $\begin{array}{l}2.00 \\
2.50 \\
3.00\end{array}$ \\
\hline
\end{tabular}

\section{COCKSPUR THORN.}

Crataegus Crux Galli, a native thorn, beautiful flowers in spring followed by red fruits in profusion in fall.

\section{Price.}

$$
\text { Each } 10
$$

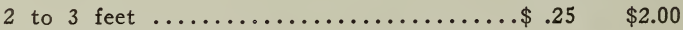

CARAGANA, Arborescens, (Siberian Pea Tree)

\section{Seven Feet.}

A valuable shrub from Siberia, delicate fern like foliage, and producing a profusion of yellow pea-like flowers in $\mathrm{May}$ and June.

\section{Price}

\section{Each 10}

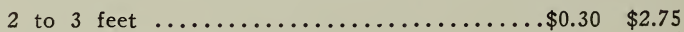

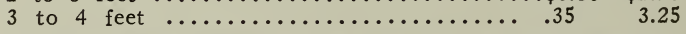

CARYOPTERIS Mastacanthus, see Spirea, Blue. Page 36. DOGWOOD, (Cornus).

* Siberian or Red Barked, (Siberica Alba) Eight feet.-Brilliant scarlet bark, fine for winter effect and a showy summer shrub.

*Stolonifera-The finest native red barked dogwood, perfectly hardy and one of the best.

* Recommended by the Illinois State Horticultu:al Society. 


\section{CORNUS-Continued}

Stolonifera, Var. Flaviramea-Yellow branched Dogwood-A form of the native Stolonifera dogwood with yellow branches; very effective for contrasts with the red barked varieties, a hand. some and valuable shrub.

Florida-The white flowered dogwood, attains the height of small tree 15 to 20 feet. A profusion of white blossoms in May, followed in the fall by red berries and brilliant foliage. An excellent variety.

Sanguinea-The old fashioned crimson barked dogwood, an excellent variety.

Mascula, Cornelian Cherry-Another excellent form of red barked dogwood. Blossoms before leaves appear followed by red edible berries.

\section{Price}

Siberian, Stolonifera, Mascula and Sanguinea Each 10

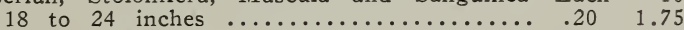

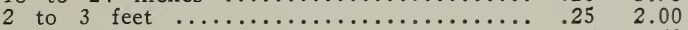

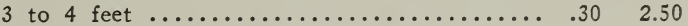

Flaviramea

18 to 24 inches, ............................ 2.50

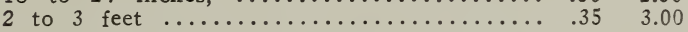

Florida

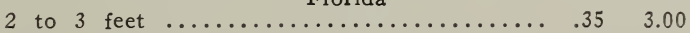

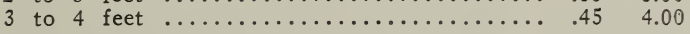

\section{DEUTZIA}

\section{Three to Four Feet}

Our assortment of Deutzia compose some of the most beautiful summer flowering shrubs we have, perfectly hardy. Their charming bell shaped flowers borne in profusion in May and June make them valuable for either massing or single specimens.

Crenata-In both double white and rose color, gives a wealth of bloom in May and June.

Gracillis-A dwarf growing variety, completely covered with small white blossoms in June: One of the best.

Pride of Rochester-A very popular sort, pure white double, large blossom and cluster. May and June.

Lemoine-Single white-Not quite as heavy a grower as Crenata but refined, and blossoms in profusion.

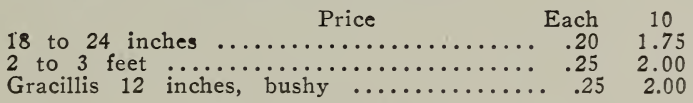

\section{ELDER}

Ten Feet

*Golden Elder-(Sambucus Aurea) - A brilliant golden leaved variety, very useful for contrasts and striking effects, becoming very popular. Can supply in large quantities up to 3 to 4 feet.

Cut Leaved-(Sambucus Laciniata) - The fern-like foliage, and drooping habit make it a valuable and artistic shrub. Always attracts attention.

Variegated-(Sambucus Variegata)-A very pretty and distinct va. riety, leaves green with white edges. 18 inches only.
18 Price Each 10

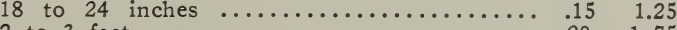

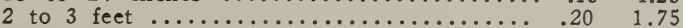

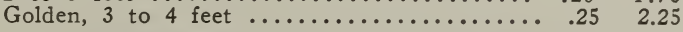

EUONYMUS-Strawberry or Spindle Tree.

Europaeus, 7 to $8 \mathrm{ft}$. - The well known strawberry tree, the fruits borne in great profusion, and their bright red color making them very attractive during late fall and winter.
3 to 4 feet $\ldots \ldots \ldots \ldots \ldots \ldots$
Price Each
10

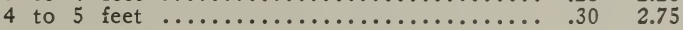

* Recommended by the Illinois State Horticultural Society. 


\section{GOLDEN BELL, (Forsythia) \\ Six to Seven Feet}

The Golden Bell, the first flowers of spring, with their brilliant color, that bloom before the buds of other shrubs have swelled, are great favorites.

Suspensa-A profuse bloomer and an attractive charming plant, with its long slender drooping branches.

Viridissima-Dark green, and upright habit of growth, also a profuse bloomer.

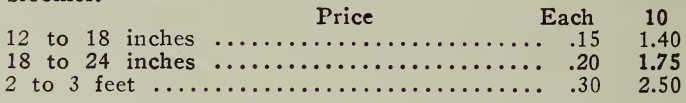

FALSE INDIGO (Amorpha Fruticosa)

Four to Six Feet

Another excellent native shrub, covered with great quantities of spikes of indigo colored flowers. Much used for massing.

$$
\text { Price Each } 10
$$

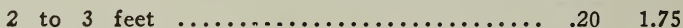

\section{"HYDRANGEA}

Paniculata Grandiflora. Six feet.-Undoubtedly the most popular shrub grown. The flowers come in late summer and last till heavy frost. They are borne in great panicles, changing from pure white to rose and bronze. Can be trained in bush or tree form.

Arborescens Sterilis. Six feet.-Sometimes called "Hills of snow," a new variety of decided merit, similar in many respects to Paniculata but commences to bloom in June and lasts till September, flowers finally changing from pure white to green. New and rare.

Price

Paniculata Grandiflora

Each 10

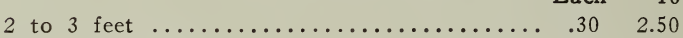

18 to 24 inches $\ldots \ldots \ldots \ldots \ldots \ldots \ldots \ldots \ldots \ldots \ldots .25 \quad 2.00$

Arborescens Sterilis

12 to 18 inches $\ldots \ldots \ldots \ldots \ldots \ldots \ldots \ldots \ldots \ldots . .30 \quad 2.50$

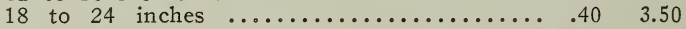

*HONEYSUCKLE, (Upright) Lonicera

Six to seven feet.- The upright honeysuckle are among the best of our shrubs, grows strong, with beautiful flowers and foliage, very sweet scented and ornamental, useful as specimen plants, clumps or hedge, flowers followed by colored fruit.

Tartarian-White, pink and red. May.

Morrowi-A valuable Japanese variety, white changing to yellow.

Price

Tartarian Upright

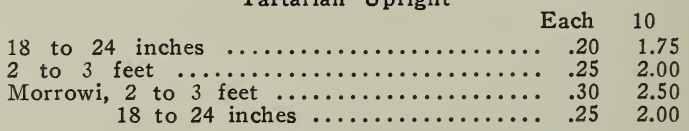

*KERRIA, JAPONICA, (Globe flower).

Flora Plena-Double yellow. One of the most beautiful and attractive shrubs from Japan. Wood and leaves a brilliant green, flowers double, yellow, rose form, blooms early in April, continuing till frost. A perfect gem.

Argenteo Variegata-Blossoms similar to the above, leaves a bright green edged with white. A slender dwarfish grower.

Rhodotypos Kerrioides-Single white,, flowers in May, very ornamental. The foliage of this plant is exceptionally fine.

* Recommended by the Illinois State Horticultural Society. 
Price Each 10

Flora Plena, 18 to 24 inches ......... $\$ 0.25 \$ 2.00$

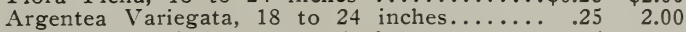

Rhodotypus, white, 18 to 24 inches ........... $25 \quad 2.00$

Rhodotypus, white 2 to 3 feet............30 2.50

\section{*LILAC, (Syringa)}

Since the introduction of the new French varieties of budded lilacs the lilac has become more popular than ever. They now compose some of the grandest shrubs we have. The budded varieties do not sucker and blossom while quite young. If you have not grown these newer sorts of lilac you have missed something. They are so perfectly hardy and of easy culture. The varieties we grow are valuable for cut flowers, remaining fresh a long time and are very profitable commercially.

Common Purple, Vulgaris, and Common White, Vulgaris Alba-The old fashioned garden sorts.

Persian Purple-Probably the most popular of all lilacs. Great loose panicles of delightfully fragrant flowers that cover nearly the entire bush. A beautiful plant for its foliage as well, which is refined and graceful.

Alfonse Lavalle-Double, immense panicles, blue lilac.

Belle de Nancy-Double, very large clusters, brilliant satiny rose with white center, having a delightful perfume. Superb.

Charles $\mathrm{X}$-Single. A strong vigorous grower, having excellent bright foliage. Large trusses, rather loose, red, tinged purple.

Frau Damman-Single, great trusses, of medium sized flowers pure white.

Josikaea-Hungarian Lilac-Single. A very fine distinct variety, forming a small tree. Beautiful purple clusters in June, after all other lilacs are done blooming.

La Tour d' Auvergne, Double-Very large blossoms, violet purple. A profuse bloomer, and very fine.

Madame Lemoine-A superb double white.

Princess Alexandra-Single, large panicles, one of the finest whites.

Pres. Grevy, Double-The flowers and panicles are very large, color, a delicate blue. A distinct and most charming variety.

Rhotomagensis-Rouen Lilac, Single-A distinct hybrid, and one of the finest, with great panicles of rosy red flowers.

Souvenir De Ludwig Spaeth-Single, long panicles, large flowers, dark purplish red, one of the best.

$$
\text { Price }
$$

$$
\text { Common Purple Each } 10
$$

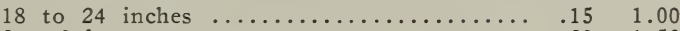

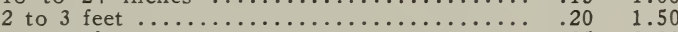

3 to 4 feet $\ldots \ldots \ldots \ldots \ldots \ldots \ldots \ldots \ldots \ldots \ldots . .25 \quad 2.00$

Common White

12 to 18 inches $\ldots \ldots \ldots \ldots \ldots \ldots \ldots \ldots \ldots \ldots .20 \quad 1.75$

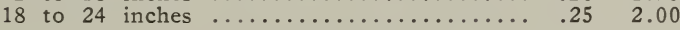

Persian

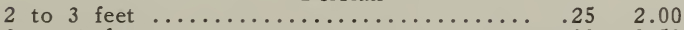

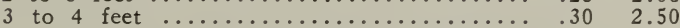

Named Varieties, Budded

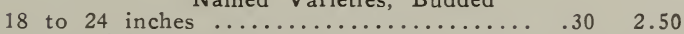

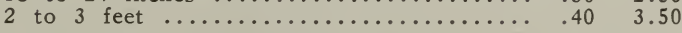

MAHONIA, Aquifolia

Four Feet

A form of barberry with large holly-like leaves, nearly evergreen, one of the most valuable shrubs, dark blue berries. This is an exceedingly beautiful and effective shrub, give a sheltered position if possible. Will become very popular when its value is appreciated.

* Recommended by the Illinois State Horticultural Society. 
PRUNUS TRILOBA, Flowering Plum.

This old but rare shrub with its great profusion of larger double pink blossoms very early in spring is a most beautiful sight. Similar to the flowering almond but bush grows larger and blossoms nearly as large as a small rose.

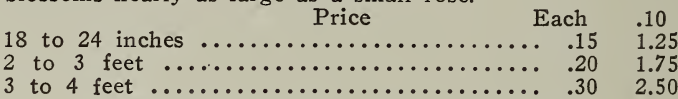

PEARL BUSH, (Exochorda Grandiflora)

Five to Seven Feet.

An exceptionally fine shrub, with its large white flowers produced in profusion during May. A rare but choice shrub.

\section{Price}

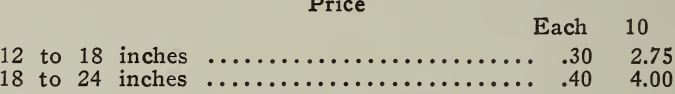

PRIVET, (Ligustrum)

Five to Six Feet

The dark green rich foliage of the privets make them valuable as in. dividual specimens or for foliage effect. They make the finest formal hedge of any plant grown. Blossoms are fragrant, attractive, resembling the lilac.

We have ceased to grow California Privet. It is not hardy in Illinois, neither will the European, Vulgaris, give satisfaction.

*Amurense, (North)-The best for hedge in the north, has stood twenty degrees below zero, upright growth.

Siberica-This is a comparatively new Privet, which we believe will become the most popular variety for hedge where hardiness is essential. Is absolutely hardy, beautiful rich green foliage and strong growers. We have only a limited supply, and offer it for the first time this year.

Regels-A grand hardy variety that has a weeping habit at ends of branches, make beautiful specimen plants, one of the hardiest.

$$
\begin{aligned}
& \text { Price } \\
& \text { Amoor River North, Amurense } \\
& 10 \quad 100
\end{aligned}
$$

2 to 3 feet, heavy $\ldots \ldots \ldots \ldots \ldots \ldots \ldots \ldots \ldots$. 1.4010 .00

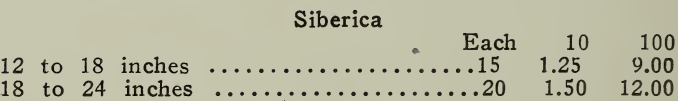

\section{Regels, Regelianum}

18 to 24 inches, each $20 \mathrm{c} \ldots \ldots \ldots \ldots \ldots \ldots \ldots .501 .5012 .50$

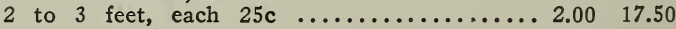

\section{RUSSIAN OLIVE, (Elaeagnus Angustifolia) \\ Ten to Fifteen Feet}

\begin{tabular}{|c|c|c|}
\hline & & \\
\hline & Each & \\
\hline $\begin{array}{l}2 \text { to } 3 \text { feet } \\
3 \text { to } 4 \text { feet } . \\
4 \text { to } 5 \text { feet } . .\end{array}$ & $\begin{array}{l}.20 \\
.25 \\
.30\end{array}$ & \\
\hline
\end{tabular}

A unique flowering tall growing shrub, resembles the olive in wood and its silver leaves, fruit bright yellow, with silver spots, very ornamental.

Price

*Recommended by the Illinois State Horticultural Society. 


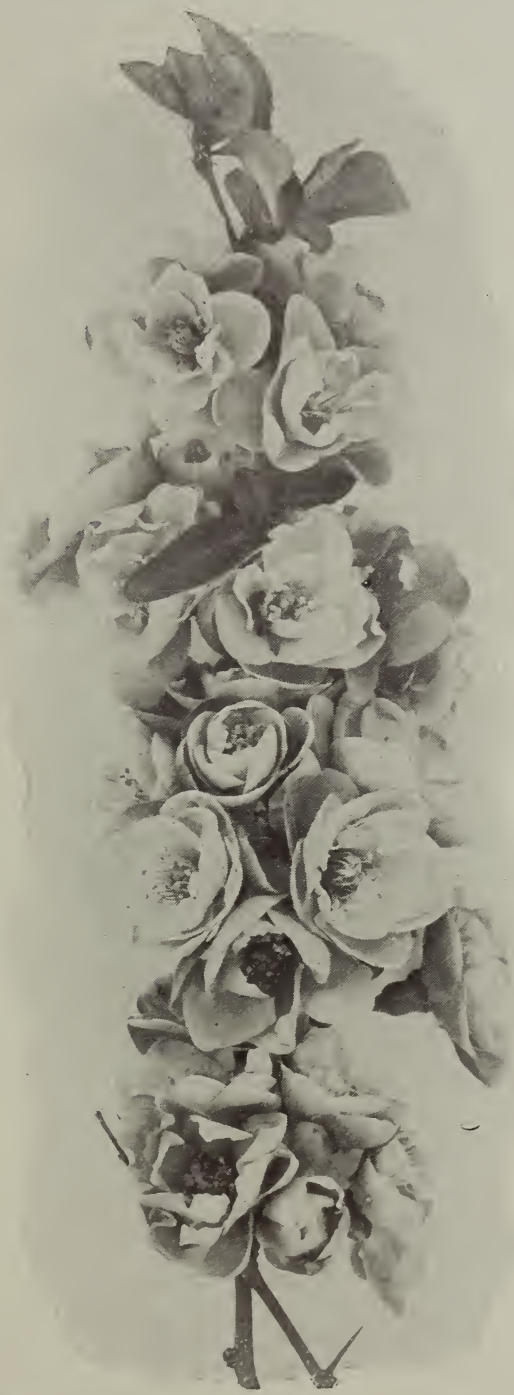

THE BEAUTIFUL JAPAN QUINCE, PYRUS JAPONICA *QUINCE, (Japanese flowering)

Pyrus Japonica-Six to eight feet-One of the finest shrubs to bloom in early spring, sometimes called "burning bush," from the profuse crimson flowers. An old garden favorite.

Price

18 to 24 inches $\ldots \ldots \ldots \ldots \ldots \ldots \ldots \ldots \ldots .20,1.50$

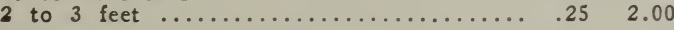

* Recommended by the Illinois State Horticultural Society. 


\section{SNOW BALL, (Viburnum)}

Common Snow Ball-Ten feet-The snow balls have always been admired. No shrub is better known, blossoming in May and June.

*Cranberry, High Bush. (Viburnum Opulus)-Seven feet-A most valuable shrub, thrives everywhere. The profuse flat clusters of white flowers change to beautiful red berries, similar to the common cranberry, and hangs on all winter. Foliage turns yellow and scarlet in autumn.

*Japanese, (Viburnum Plicatum) - Six to seven feet-A new variety from Japan, superior to the common in foliage and flower, blooms later and lasts longer than the common. More dwarfish and compact.

Wayfaring Tree, (Viburnum Lantana)-Large dense heads of white flowers followed by bright red berries, gradually changing to darker color. The foliage is heavy leaves, thick dark green changing to rich purple in the fall. One of the handsomest strong growing shrubs we have.

$$
\text { Price Each } 10
$$

\section{Common Snowball}

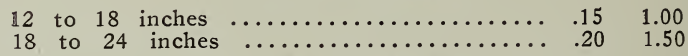

12 to 18 inches $\begin{aligned} & \text { Cranberry, High Bush } \\ & \ldots \ldots \ldots \ldots \ldots \ldots \ldots \ldots \ldots \ldots \ldots \ldots \ldots \ldots \ldots \ldots\end{aligned}$

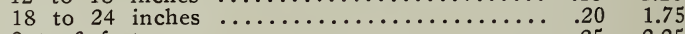

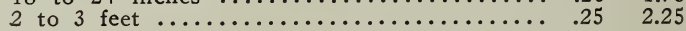

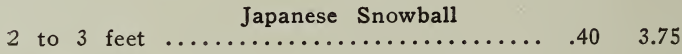

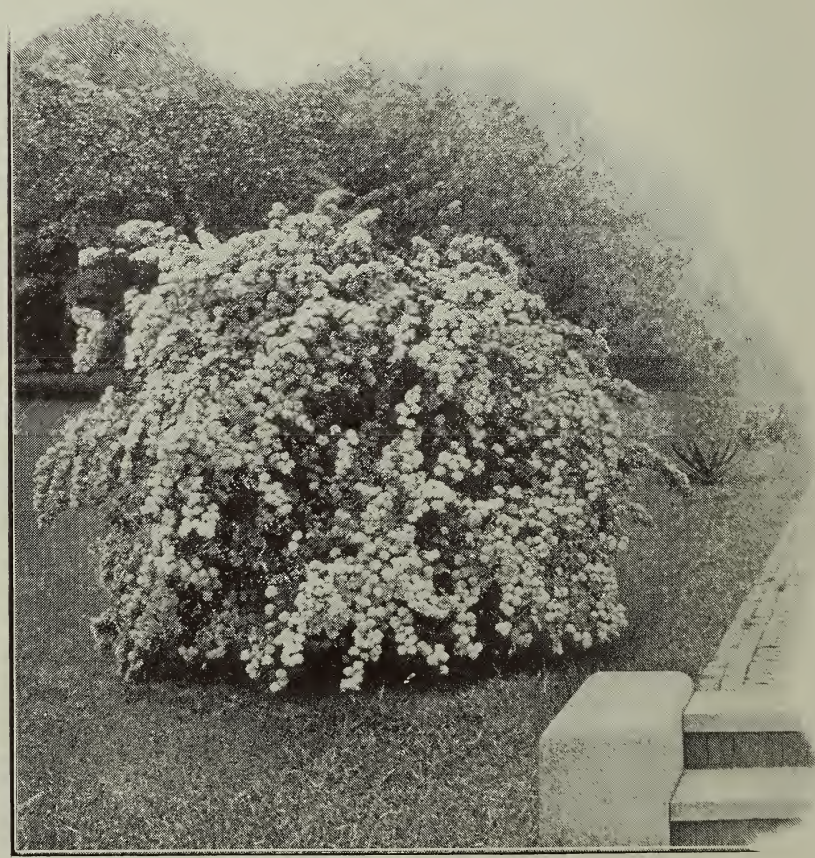

THE DAINTY BRIDAL WREATH, SPIREA VAN HOUTTEI

${ }^{*}$ Recommended by the Illinois State Horticultural Society. 
Wayfaring Tree

18 to 24 inches $\ldots \ldots \ldots \ldots \ldots \ldots \ldots \ldots \ldots \ldots \ldots .20 \quad 1.75$

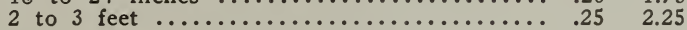

SPIREAS, (Meadow Sweet).

Of all the summer blooming shrubs probably none are more used than the Spireas, some of the varieties giving bloom from early spring till frost.

*Anthony Waterer, Bumalda-Three feet-Crimson, profuse bloomer, flowers all summer.

Billardii-Commences to bloom in June and lasts till September. Beautiful pink spikes in profusion. An old time favorite.

Callosa Alba-Two feet-Pure white, with beautiful masses of flowers all summer.

Opulifolia Aurea-Four to five feet. The golden leaved spirea blos. soming in June, is one of the most charming of the group, both for its golden foliage and the clusters of flat blossoms-very ornamental and deserves its popularity.

Reevesiana-Beautiful white flowers in early spring.

Thunbergii-Three feet-The fine, delicate, slender leaves and branches of the Thunbergii, with its profuse blossoms in early M2y makes it especially valuable for planting at base of the taller shrubs-one of the best.

Van Houttei, Bridal Wreath-Three to four feet-The most popular of the spireas, when in bloom one of the most charming shrubs in existence. The drooping branches are a mass of white bloom to the tips, foliage also very pretty.

\section{Price Each 10}

Anthony Waterer's-Bumalda, 12 to 18 inches $.25 \$ 2.00$

Billardii, 12 to 18 inches $\ldots \ldots \ldots \ldots \ldots \ldots \ldots .20 \quad 1.50$

18 to 24 inches $\ldots \ldots \ldots \ldots \ldots \ldots \ldots \ldots .25 \quad 2.00$

2 to 3 feet ......................... 2.50

Callosa Alba, 18 to 24 inches.................. 2.50

Opulifolia Aurea, 18 to 24 inches............. $25 \quad 2.00$

2 to 3 feet..................... 20

Reevesiana, 18 to 24 inches ................ $20 \quad 1.50$

2 to 3 feet $\ldots \ldots \ldots \ldots \ldots \ldots \ldots . . \ldots \ldots . .25 \quad 2.00$

Thunbergii, 12 to 18 inches .................. 1.50

18 to 24 inches............... $25 \quad 2.00$

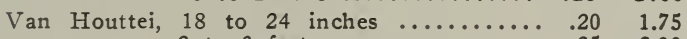

2 to 3 feet $\ldots \ldots \ldots \ldots \ldots \ldots \ldots . .25 \quad 2.00$

3 to 4 feet $\ldots \ldots \ldots \ldots \ldots \ldots \ldots . .30 \quad 2.50$

*SYRINGA, (Philadelphus)

Coronarius-Mock Orange-Five to seven feet-These deliciously fraggrant old fashioned shrubs are as popular as ever. The great clusters of snow white blossoms fill the air with perfume during June.

Grandeflorus-Similar to Coronarius, except two to three weeks later, blossoms are much larger, and without odor. A grand variety and very popular.

Avalanche-More slender and graceful than the above. The long arching of branches almost covered their entire length with a profusion of snow white flowers.

Zeyheri-A hybrid of Coronarius, fragrant, more spreading, branches drooping somewhat, flowers large. A very attractive and charming shrub.

\section{Price}

Coronarius and Grandeflorus. Each 10

12 to 18 inches $\ldots \ldots \ldots \ldots \ldots \ldots \ldots \ldots \ldots \ldots . .15 \quad 1.00$

18 to 24 inches $\ldots \ldots \ldots \ldots \ldots \ldots \ldots \ldots \ldots \ldots . .20 \quad 1.75$

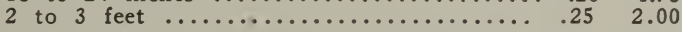

Avalanche and Zeyheri

18 to 24 inches $\ldots \ldots \ldots \ldots \ldots \ldots \ldots \ldots \ldots \ldots \ldots .3 n \quad 2.50$

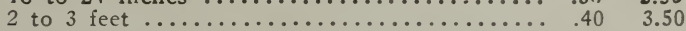

"Recommended by the Illinois State Horticultural Society. 


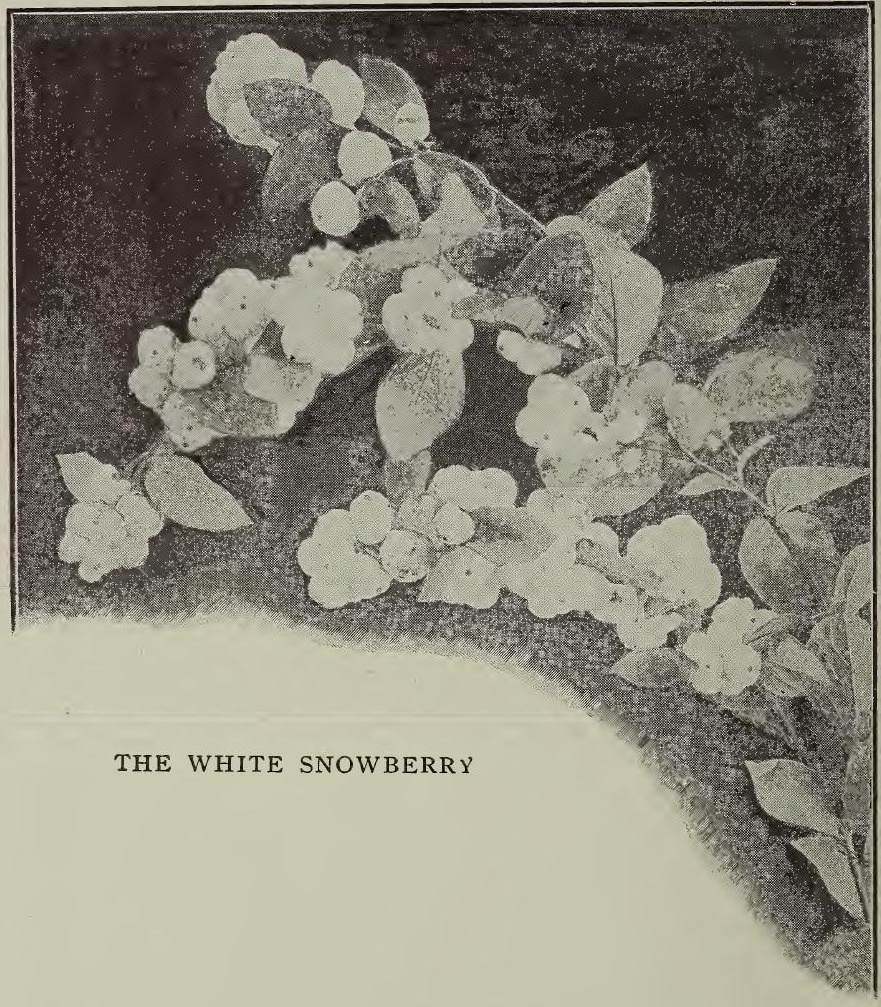

SUMACH, (Rhus)

*Fern Leaved, Rhus Typhina Laciniata-One of the few tropical looking shrubs reminding one of a small fern tree. No plant we have has atracted more attention. Turns to golden in fall.

Staghorn, Typhina-Eight to ten feet-A grand striking plant, with its great panicles of highly colored fruit, and foliage in autumn.

\section{Price}

Fern Leaved, 2 to 3 feet, each 30 cts., per $10 \ldots \ldots \$ 2.50$

3 to 4 feet, each 40 cts., per $10 \ldots \ldots 3.50$

Staghorn, 18 to 24 inches, each 20 cts., per $10 \ldots \ldots .1 .50$

2 to 3 feet, each 25 cts., per $10 \ldots \ldots \ldots \ldots \ldots 2.00$

SNOW BERRY (Symphoricarpos)

Four to Five feet.

There is probably no plant that will continue to do its part to beautify the surroundings under adverse conditions better than the Snowberries, and when winter comes their beauty is even enhanced with their drooping branches loaded with bright berries.

Racemosus, White Snowberry-Beautiful in foliage, flowering in clusters through the summer and followed by quantities of large white berries. Very effective.

"Recommended by the Illinois State Horticultural Society. 
Vulgaris, Coral Berry-Similar to the above except the blossoms are followed by small red berries. Valuable for shady places.

\section{Price}

Racemosus 18 to 24 inches, each 25 cts., per $10 \ldots \$ 2.00$

2 to 3 feet, each 30 cts., per $10 \ldots \ldots 2.50$

3 to 4 feet, each 35 cts. ................. 3.00

Vulgaris, 18 to 24 inch, 20 cts., per $10 \ldots \ldots \ldots \ldots . . . \ldots \ldots$

2 to 3 feet, each 25 cts., per $10 \ldots \ldots \ldots 2.00$

3 to 4 feet, each 30 cts., per $10 \ldots \ldots 2.50$

*TAMARISK, (Tamarix).

Gallica and Indica-Eight to ten feet-Beautiful shrubs with feathery asparagus like foliage, pinkish white blossoms in June and July, decidedly picturesque.

\section{Price}

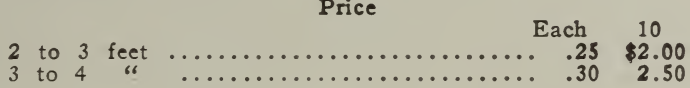

\section{WEIGELIA. (Diervilla).}

Six Feet.

Rosea-Beautiful, well known shrub with rose colored flowers, coming in May and June. Strong growing graceful spreading branches.

Candida-White. One of the most deservedly popular of all the Weigelias, with its large tubular shaped white flowers, in long sprays during July.

Pres. Duchartre-An improved form of Rosea of French origin.

\section{Price}

Rosea, 18 to 24 inch, each 25 cts., per $10 \ldots \ldots \ldots 2.00$ 2 to 3 feet, each 30 cts., per $10 \ldots \ldots \ldots \ldots \ldots 2.50$

Candida, 18 to 24 inches, each 25 cts.,., per $10 \ldots \ldots 2.00$ 2 to 3 feet, each 35 cts., per $10 \ldots \ldots 3.00$

Pres. Duchartre, 18 to 24 inches, each 30 cts., per 102.50 2 to 3 feet, each 35 cts., per $10 \ldots \ldots . . .3 .00$

\section{WITCH HAZEL.}

Hammamelis Virginica-A native shrub, excellent foliage, flowers yellow, late in fall, just before leaves fall.

\section{Hardy Vines}

\section{BITTER SWEET, STAFF VINE, (Celastrus Scandens).}

One of the best of our native vines, a strong grower, beautiful foliage, and in the fall covered with orange red berries.

Price, strong plants, each 25 cts., per $10 \ldots \ldots \ldots \$ 2.00$

\section{CLEMATIS}

- Japanese Paniculata-Deservedly one of the most popular vines grown. Is rapid growing, dense foliage of brilliant green. In September is completely covered with a profusion of dainty star shaped, white blossoms that are deliciously fragrant.

Virgin's Bower, Virginiana-The popular native sort, 'arge leaves, robust grower, blossoms a month earlier than Paniculata and similar to it. An old time favorite.

\section{LARGE FLOWERING CLEMATIS}

Admired by all and very popular, strong field grown plants.

* Jackmani-Large showy purple, single the best.

Henryi-Large single white, the best large white.

* Recommended by the Illinois State Horticultural Society. 


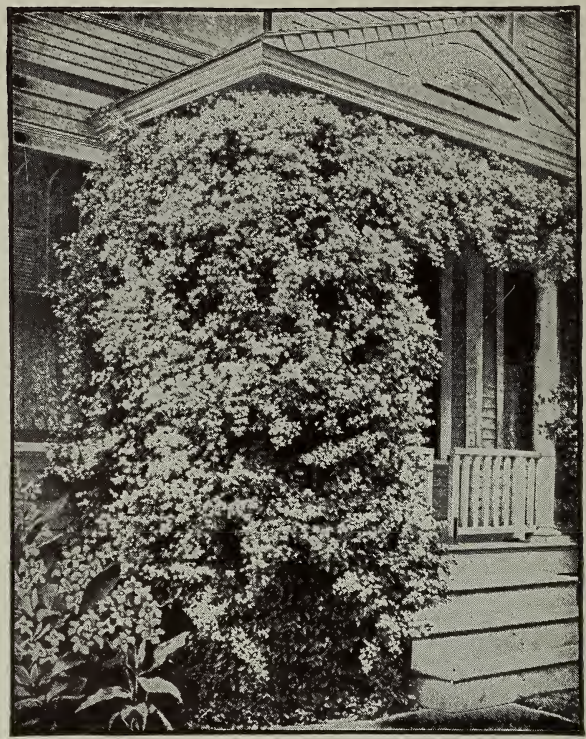

CLEMATIS PANICULATA

Price

All strong, 2 and 3 year plants. Each 10

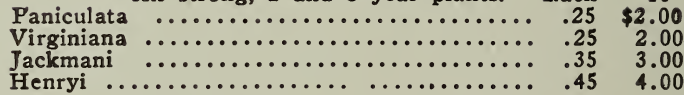

DUTCHMAN'S PIPE-(Aristolochia Sipho)

A very striking and handsome climber, native of America. The leaves are 10 to 12 inches in diameter, and curious brownish colored, pipe shaped flowers. Perfectly hardy.

\section{Price}

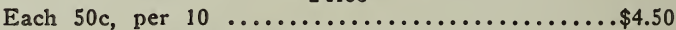

\section{EUONYMUS RADICANS}

An exceedingly ornamental evergreen climber, with small rich green foliage. Bears a quantity of pink berries that turn scarlet as they open. Clings readily to tree trunks and rough walls.

\section{Price}

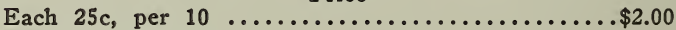

HONEYSUCKLES, (Lonicera).

Still remain favorites and as popular as ever. Excellent for coverine porches, trellis or fences.

*Hall's Japan, Halliana-Almost an evergreen, and a very popular variety. The fragrant white and yellow blossoms borne in profusion all summer.

Monthly Fragrant, Belgica-A beautiful type, bearing flowers all summer.

* Scarlet Trumpet, Sempervirens-Sometimes called the coral honeyhoneysuckle. A handsome vine, large showy leaves, long scarlet flowers, borne in profusion all summer.

Yellow Trumpet-Identical to Scarlet Trumpet except the blossoms are yellow. One of the best of the honeysuckles.

- Recommended by the Illinois State IIorticultural Society. 


\section{Price}

Field grown, strong two year vines.

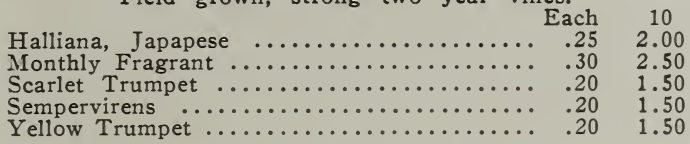

IVY, (Ampelopsis).

*Boston Ivy, Ampelopsis Veitchi-The most popular and beautiful vine for covering stone or brick building, clinging tenaciously, beautiful shades of green in summer, changing to crimson and gold in autumn.

*Virginia Creeper or Woodbine, Ampelopsis Quinquefolia-Clings to trees and walls, very pretty for trellises and natural effects. Leaves turn crimson in autumn. One of the good native vines.

Ampelopsis Englemani-Resembles Ampelopsis Quinquefolia, except that it clings to walls much better. It is one of the finest Ivies we have. The brilliant coloring of the leaves in Autumn, together with perfect hardiness, make it a very valuable climber.

Strong two year plants,

\section{Price}

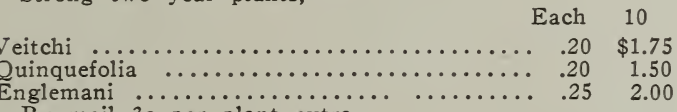

By mail 3c per plant extra.

\section{KUDZU VINE (Pueraria Thunbergiana)}

Leaves large and dense, blossoming quite profusely in August and September. Makes 40 to 50 feet growth in a single season. The long racemes of rosy purple, pea-shaped. flowers are very attractive.

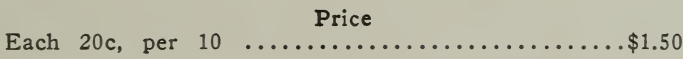

\section{MATRIMONY VINE.}

Lycium Barbarum-Can be used either as a vine or a shrub. Handsomer in the latter form, producing a close compact rounded clump. Will grow in shade or poorest soil. Produces a profusion of large scarlet berries in the fall. A valuable plant not sufficiently known or appreciated.

\section{Price}

Strong plants.

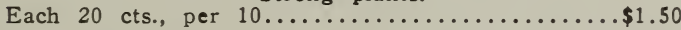

\section{TRUMPET VINE.}

Bignonia, Radicans-The well known trumpet vine with its large scarlet trumpet shaped blossoms. Very picturesque, with its gorgeous display of brilliant flowers in July and August. Excellent for covering stumps and dead trees.

\section{Price}

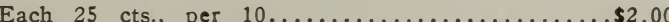

\section{WISTARIA}

* Chinese Purple, Sinensis-One of the most cliarming and beautiful of vines, with great pendulous racemes of purple flowers.

*Chinese White, Sinensis Alba-The white form of the above, 2 little slower in growth, profuse bloomer.

\section{Price}

$$
\text { Each } 10
$$

Purple, Sinensis ...................40 \$3.50

White, Sinensis Alba ................ .6. $60 \quad 5.00$

* Recommended by the Illinois State Horticultural Society. 


\section{Roses}

\section{CLIMBING ROSES.}

The New Blue Rose-Veilchenblau-The greatest novelty ever in. troduced in roses. Rose growers have tried for centuries to produce a Blue Rose, and at last it has come. Perfectly hardy, a vig. orous climber, and excellent foliage. Borne in great clusters similar to Crimson Rambler, but a delicate Corn Flower Blue.

Baltimore Belle-A strong climber, blossoms very double, carmine rose tint. Foliage good, flowers produced in great profusion.

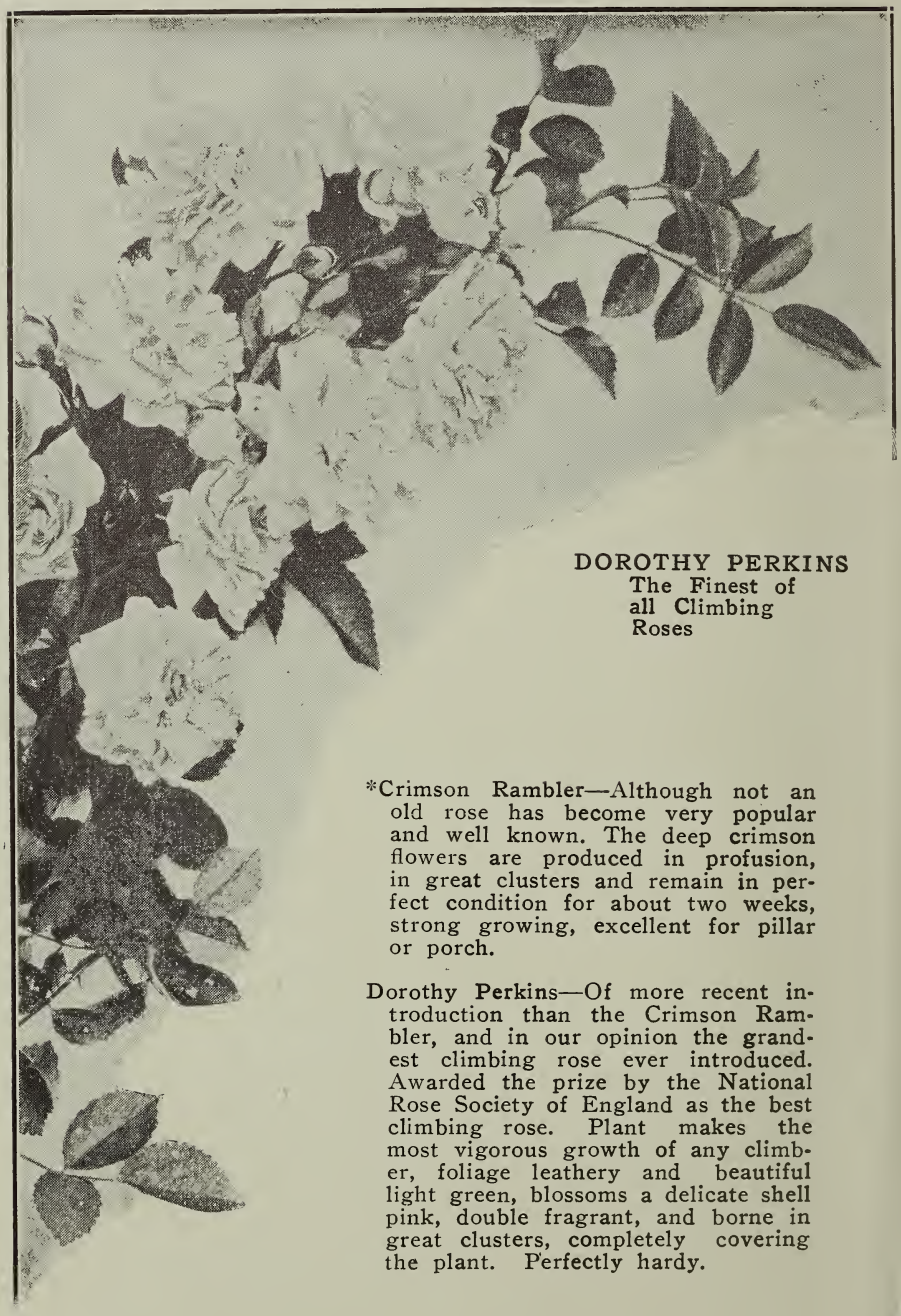

*Recommended by the Illinois State Horticultural Society. 


\section{CLIMBING ROSES-Continued}

Lady Gay-A most charming rose and strong grower, perfectly hardy. Blossoms are a delicate cherry pink, gradually changing to a lighter shade. One of the best climbers.

Prairie Queen-This is probably the best known of all the old-fashioned climbers. A large rose, borne in great abundance, very double, globular, color a brilliant pink.

Seven Sisters-An old garden favorite, giving a profusion of crimson bloom, changing to white in different shades.

\section{DWARF ROSES}

Baby Rambler, Crimson-Valuable for outside and inside planting, very similar to the Crimson Rambler in habit of blooming, plants are a continuous mass of bloom from early spring till frost, a great bedding rose.

* Baby Dorothy-This new rose deserves as much praise as the Dorothy Perkins. Beyond question the handsomest of the baby or dwarf type, a delicate shell pink, with beautiful pointed buds and when tested in our trial grounds this past summer, there was not a day from early May till frost that a single plant did not carry from 25 to 100 blooms. As a bedding plant we doubt if it has an equal. Perfectly hardy. We have a fine stock of splendid plants, imported from France.

HYBRID PERPETUAL AND MISCELLANEOUS ROSES.

Persian Yellow-The old favorite hardy yellow rose, blooms early in spring. The first of all roses to bloom.

*Killarney-A beautiful pink rose, profuse bloomer all summer. Give slight protection in winter.

*Kaiserin Augusta Victoria-Pure white with cream center, splendid outdoor bloomer, slight protection.

*LaFrance-A well known free blooming silver pink rose, very fragrant, slight protection.

Madam Plantier-A pure white rose, blooming in great profusion, and much used for Cemeteries and lawns. Perfectly hardy. An old favorite.

Rugosa, Japanese Rose-This rose is deservedly very popular, used as a shrub it is fine. The foliage is refined and charming all summer, the blossoms are large single, produced throughout the summer, followed by large crimson fruits, perfectly hardy and one of the most beautiful shrubs grown.

\section{Price}

Strong two-year, field grown plants,

Veilchenblau-The new Blue Rose.......... .35 $\$ 3.00$

All other Climbing Roses..................... $25 \quad 2.00$

Dwarf or Baby Roses.

Baby Rambler, red $\ldots \ldots \ldots \ldots \ldots \ldots \ldots \ldots \ldots . .30 \quad 2.50$

Baby Dorothy, pink ..................... $.40 \quad 3.50$

Other Hardy Roses. General Jacqueminot
a Victoria

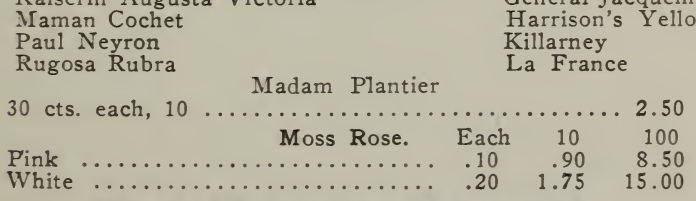

\section{Hardy Herbaceous Perennials}

There is probably no class of plants that has grown so rapidly into popularity of recent years as the hardy perennials. Why these old fashioned flowers that our Grandmothers prized so highly have been for a time neglected is hard to say, but be that as it may they are being appreciated now as never before.

They are perfectly hardy, of the easiest culture, and by selection, beautiful flowers suitable for the garden or cut flowers can be had with but little expense or trouble from early spring till after frost.

The Perennial Garden or Border is indispensable to the home like grounds.

"Recommended by the Illinnis State Horticultural Society. 


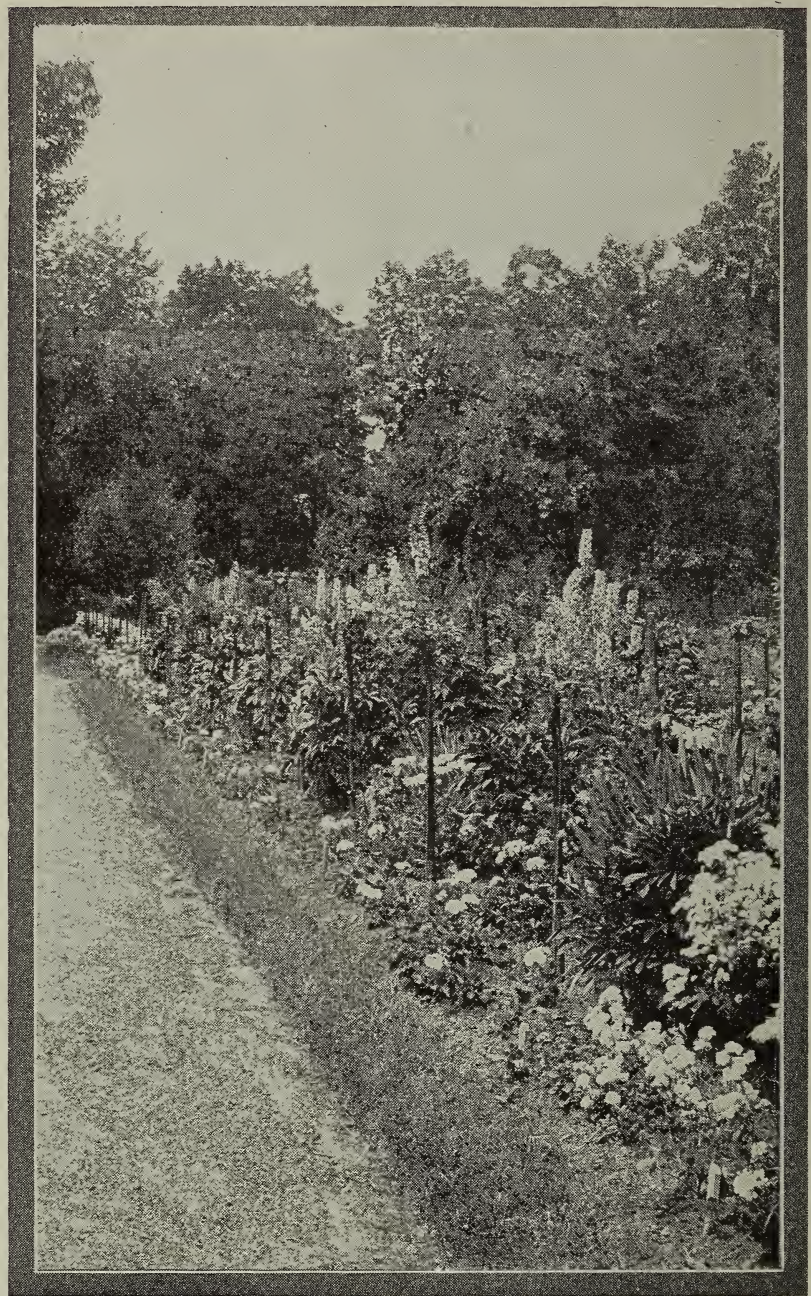

\section{WHAT IS MORE BEAUTIFUL THAN A WELL CHOSEN}

We shall be pleased to assist you in making selections, or assist you to plan the border or formal garden. We have in our gardens over 500 varieties of perennials, practically everything of value in this climate. Some varieties that are valuable elsewhere are worthless in the Mississippi valley.

Achillea-Yarrow-12 to 18 inches.

The Pearl-Blooms in profusion all summer, and the pure white flowers are excellent for cutting. One of the finest bedding plants we have. Perfectly hardy. Price: each 10c; per 10,90c.

Millefolium Roseum-The flowers are a beautiful pink and the fine feathery foliage makes it very attractive. Blooms all summer. Price: each $15 \mathrm{c}$; per $10, \$ 1.50$. 


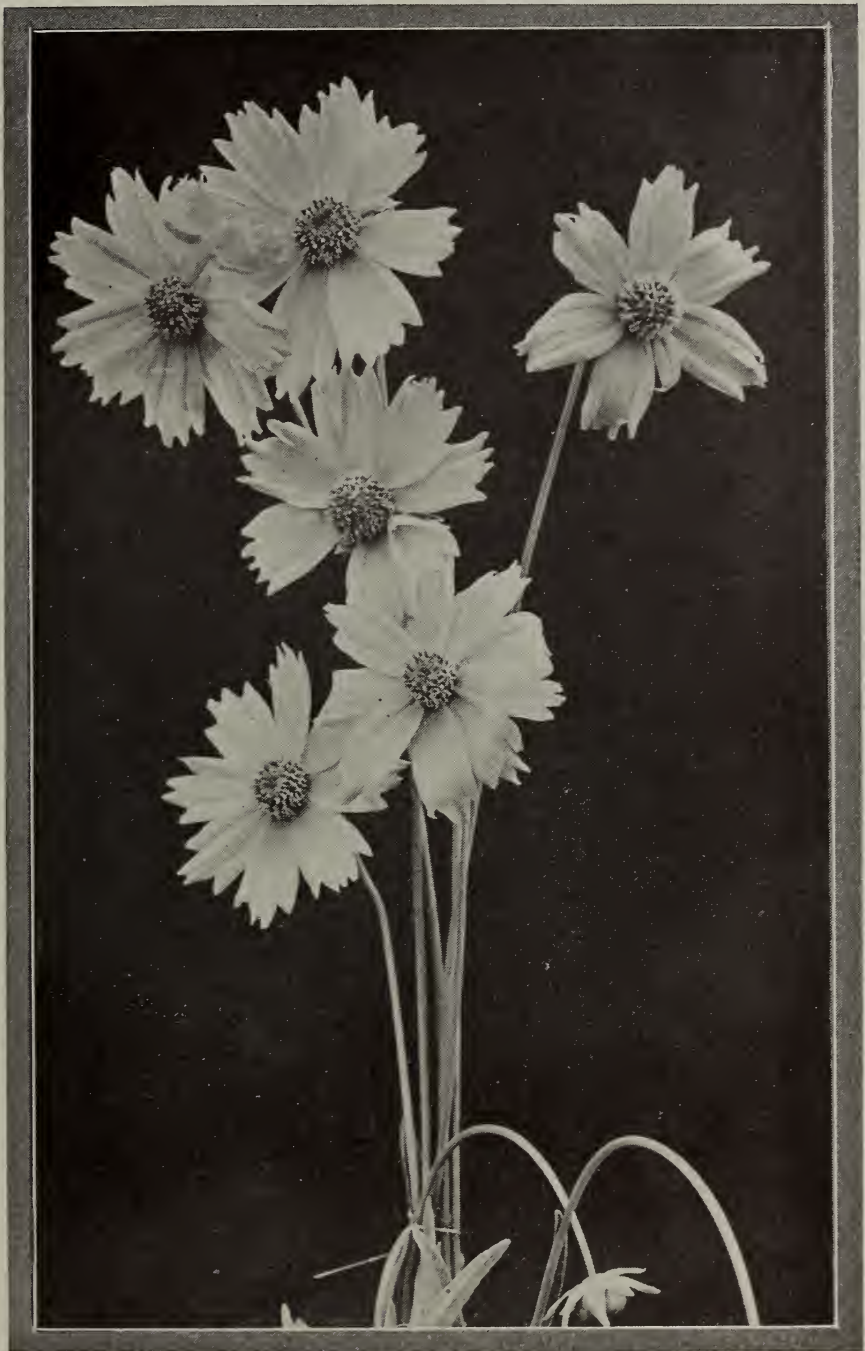

\section{COREOPSIS LANCEOLATA}

Aegyptica-Identical to Millefolium Isoseum except the flowers are a bright yellow. Price: each, $20 \mathrm{c}$; per $10, \$ 1.50$.

*Adams Needle, or Spanish Bayonet. Yucca Filamentosa-An evergreen, tropical looking plant, resembling the century plant somewhat. Large white waxy, bell-shaped blossoms borne on branches from a tall central spike $\mathrm{s}^{-}-$feet high. A very showy and valuable plant. Price: each. $10 \mathrm{c}$, per $10, \$ 1.25$.

Anemone Canadian-(Pennsylvanica)-The only Anemone we have found that is perfectly hardy here. A profuse bloomer, star like flowers of pure white, from early June till August. VIakes fine clumps. Each $15 \mathrm{c}$, per $10 \$ 1.25$.

* Recommenaed by the Illinois State Hnrtirultural Society. 


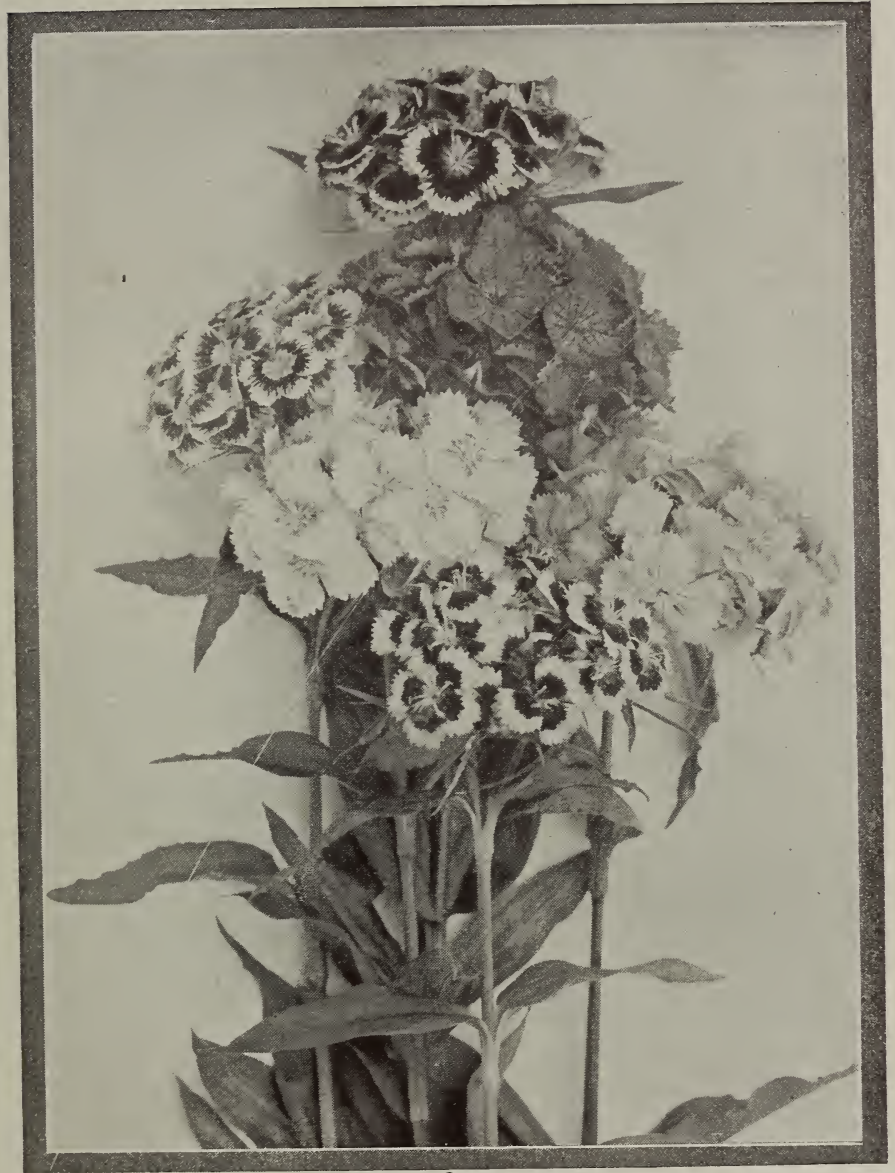

\section{DIANTHUS BARBATUS, THE POPULAR OLD FASHIONED SWEET WILLIAM IN ALL COLORS}

Delphinium-Hardy Larkspur-The best and finest variety of Larkspur, blooming continuously throughout the summer, clear turquoise blue. Price, each, 25 cts., per $10, \$ 2.00$.

Giant Daisies, Pyrethrum Uliginosum-Two to three feet. Large daisy like flowers, white with yellow center, with long stems in August and September. One of the few valuable late white flowers. Excellent for cutting. Each, $15 \mathrm{c}$; per $10, \$ 1.25$.

Gaillardia, Blanket Flower-18 inches, Kelways-The finest strain of this wonderful bedding plant. Petals orange tipped with red base. Valuable for cut fiowe-s and blooms continuous. ly from early spring till frost. Probably there is no perennial equal to the Gaillardia for Illinois. Each, $15 \mathrm{c}$; per $10, \$ 1.25$.

Golden Glow-See Rudbeckia.

Day Lily-Hemerocallis Kewanso-Two feet. The well known Golden Day Lily, blooms in July and August. An old favorite and deserving. Each, $10 \mathrm{c}$; per 10, 80c.

We have in limited quantities 10 other varieties of Hemerocallis, $15 \mathrm{c}$ to $50 \mathrm{c}$ each. 


\section{Helianthus-Hardy Sunflowers.}

Mollis Grandiflorus-Medium size, single, five feet. Each 10c; per $10,90 \mathrm{c}$.

Orgyalis-Small, single flowers in great profusion, odd and very handsome in flower and leaf. Each $15 \mathrm{c}$; per $10, \$ 1.25$.

Heliopsis-Ten feet-Similar to sunflower,

Pitcherina-Single small flowers and Sparsifolia, larger single. Each, $15 \mathrm{c}$; per $10, \$ 1.25$.

Lychnis Chalcedonica-Ragged Robin-An old time garden flower, suitable for cutting, all summer. Crimson. Each, 10c; per 10, $90 \mathrm{c}$.

Pinks-Hardy-Her Majesty, pure white double, the finest white and one of the most beautiful garden flowers. All summer. Each $15 \mathrm{c}$; per $10, \$ 1.25$.

Mrs. Augustine-This is the most charming pink we have ever seen. It was found some years ago in an old garden here at Normal. A brilliant crimson, blooms profusely from early spring till frost. Resembles a high class carnation more than any other hardy pink. Does as well indoors as out. A most refined and valuable flower. Perfectly hardy. Supply limited for this year. Each 50c, per 10, $\$ 4.50$.

Physostegia-American Heather-Three feet. Virginica-Tall spikes of pink flowers, profuse bloomer and an old time favorite. Fine for cutting.

Virginica Alba-Same as the above but white. Price: each, 10c; per $10,90 \mathrm{c}$.

Phlox-Of all the hardy flowers there is nothing except the peonies to compare with the newer strains of hardy phlox. By selection a continuous supply of bloom can be had from early summer till frost. With their wealth of color they are probably the most valuable of all decorative perennials. We have in stock one of the largest and most desirable assortments possible to collect. We herewith list only a few but can supply in a limited way 100 of the best garden sorts.

Coquelicot-Pure scarlet, deep carmine eye. One of the brightest.

F. Y. Von Lassburg-Immense trusses of pure white tall growing. Large individual flowers.

Flora Horning-Immense blossoms, outer edge of petals, white with a crimson eye. The most handsome phlox grown.

Jeanne de Arc-Pure white, blossoms medium size but trusses very large. Very fine and showy.

Hermine-Very dwarf and compact, pure white, fine.

Mrs. A. Baker-Free flowering, light crimson.

Miss Linguard-The earliest of all. Pure white, profuuse blocmer and considered by many the finest of all phloxes.

Tapis Blanc-A new rare dwarf white. In our opinion the finest phlox grown. Immense pure white blossoms in large solid panicles.

Each 15c; per 10, $\$ 1.25$; except Tapis Blanc and Flora Horning-add $10 \mathrm{c}$ each per plant to these prices.

Mixed varieties all colors not named, strong plants, each $10 \mathbf{c}$, per $10,90 \mathrm{c}$; per $100, \$ 8.00$.

Rudbeckia-Brilliant Cone Flower.

Lanceolata-The well known Golden Glow. Each, 10c; per $10,75 \mathrm{c}$.

Newmani-Black Eyed Daisy-Two feet. One of the showiest of all the hardy flowers. Profuse bloomer from July till frost. Large yellow daisy like flowers with dark brown center. Fine for cutting and last a long time. Each $15 \mathrm{c}$; per $10, \$ 1.25$.

Paeonia, Peonies-Undoubtedly one of the finest of all hardy garden flowers, succeeding everywhere, and excellent for cut flowers. We are giving a great deal of attention to peonies, and are growing 150 varieties, including the best of the Japanese, European and American varieties, many of these deliciously fragrant. We catalog only a few sorts and will be glad to correspond with persons interested. 


\section{Prices}

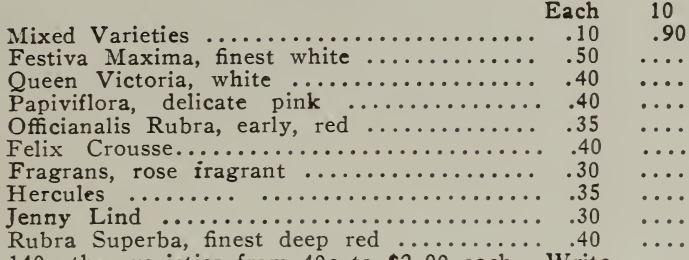

140 other varieties from $40 \mathrm{c}$ to $\$ 2.00$ each. Write

for list and prices.

Mallow, Crimson Eye-These magnificent thrifty plants bear a profusion of very large flowers from five to seven inches across, pure white with a crimson eye, highly decorative from July to September. Price: each, $20 \mathrm{c}$; per $10, \$ 1.50$.

Iris-The German-Fleur de Lis-and the gorgeous Japanese varieties, especially the newer introductions have made this old time favorite more popular than ever. We have one of the finest collections in this country, consisting of seventy-five varieties. We will gladly assist those desiring to plant a collection of these popular favorites.

$\begin{array}{lcc}\text { Price } & \text { Each } & 10 \\ \text { Germanica, Assorted } \ldots \ldots \ldots \ldots \ldots \ldots \ldots \ldots \ldots & .15 & 1.25 \\ \text { Japanese, assorted } \ldots \ldots \ldots \ldots \ldots \ldots \ldots \ldots \ldots & .25 & 2.00\end{array}$

Lily of the Valley-These delicate sweet scented lilies, coming in the month of May, well deserve their popularity.

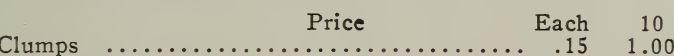

Tritoma-Pfitzerii-Flame Flower-Or Red Hot Poker. This new type of tritoma is more like a stalk of flame than anything else. Throws up a stalk two feet tall surmounted by a great mass of flaming crimson and orange colored flowers, from early September till frost, making the grandest show imaginable. Price, each, 20c; per 10, \$1.75.

Grasses-Ornamental

Phalaris-Arundinacea Variegata-A low growing variegated ribbon grass. Very useful for bordering beds and walks. One of the most popular grasses.

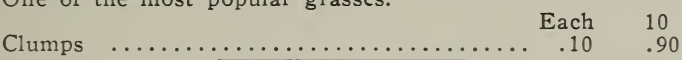

\section{Dahlias}

It is surprising the little attention Dahlias receive in the middle west.

We believe this is due in a great measure to the lack of know. ing how to treat them. Notwithstanding the extremely dry summer just past, the worst for Dahlias in years, we had a most gorgeous show of Dahlias from the last of July till the first of November.

Cultural Directions:-Plant in good quality of garden soil that is porous, where they will receive the full sun. Plant not closer than 2 1-2 feet apart, and at least six inches deep. The soil should be prepared very deep, fully a foot or two is better.

At first cover about two or three inches, and when the stem pushes through the ground fill in with balance of dirt.

Lay the tuber down flat, and allow but one sprout to each plant, which should be pinched back as soon as three sets of leaves have formed. This makes a stocky branched plant that will not need staking. In the latitude of Central nlinois plant from May 15 to June 1st. Wait till the ground is thoroughly warm, and all danger of frost is past. If you follow these directions you will have an abundance of flowers provided you cultivate thoroughly and con. tinuously till plants are in bloom.

We have about two hundred varieties best suited to the trying conditions of this climate and will be pleased to make special prices on large collections and varieties not listed.

Allow 2 cents extra by mail, prepaid. 


\section{CACTUS DAHLIAS}

These are a distinct class, having long narrow pointed and sometimes twisted petals, they have been one of the most remarkable developments of this wonderful flower. Very attractive and showy. Rivaling the choicest of the chrysanthemums.

Alfred Vasey-Reddish amber, with pink edge, excellent, free, each, $25 \mathrm{c}$; per $10, \$ 2.00$.

Bornemann's Liebling-Delicate soft rose pink, fine, each $20 \mathrm{c}$, per $10, \$ 1.50$.

Countess of Lonsdale-Deep salmon red, one of the best, each 20c, per $10, \$ 1.50$.

Clara G. Stedwick-Clear bright salmon, large and free. Each 20c, per $10, \$ 1.50$.

Crimson Cactus-An excellent free blooming standard variety. Each $15 \mathrm{c}$, per $10, \$ 1.00$.

Dr. Jameson-Deep rich crimson, free bloomer. Each $10 \mathrm{c}$, per $10, \$ 0.75$

Hetty Dean-Bright shade of amber, and very profuse. Each, 20c, per $10, \$ 1.50$.

Island Queen-Light mauve shade, good form and free. Each 10c, per $10, \$ 0.75$.

Kriemhilda-Brilliant pink, shading to white in center, extra good. Each $20 \mathrm{c}$, per $10, \$ 1.50$.

Mrs. Chas. Turner-Clear delicate yellow, fine, large form. Each, $10 \mathrm{c}$, per $10 \$ 0.75$.

One each of the above for $\$ 1.40$, by mail prepaid, $\$ 1.60$

One each of 20 varieties for $\$ 2.50$, by mail prepaid, $\$ 2.90$

\section{DECORATIVE DAHLIAS}

These Dahlias are midway between the Cactus and Show. Large, open-faced with long flat petals. Not quite so formal as the show type Lyndhurst-Brilliant cardinal red, much used for cut flowers. Each $15 \mathrm{c}$, per $10, \$ 1.25$.

Nymphaea-Delicate shrimp pink, water lily type. Each $15 \mathrm{c}$, per $10, \$ 1.00$.

Perle de la Tete d' Or-Pure white deeply cut, similar to chrysanthemum. Each $20 \mathrm{c}$, per $10 \$ 1.75$.

Progress-Lavender, with stripes and blotches of soft crimson, delicate and fine. Each, $20 \mathrm{c}$, per $10, \$ 1.75$.

Souvenir de Gustave Douzon-Orange red, very large and free, fine. Each $15 \mathrm{c}$, per $10, \$ 1.25$.

Sylvia-Cream white, edged with pink, a splendid flower. Each $15 \mathrm{c}$, per $10, \$ 1.25$.

One each of the above 6 varieties $90 \mathrm{c}$, mail prepaid $\$ 1.02$.

One each of 12 varieties, $\$ 1.75$, mail prepaid $\$ 2.00$.

\section{SHOW DAHLIAS}

These have quilled petals, and more ball-shaped, compact, having the well known dahlia form.

A. D. Livoni-A delicate rose pink, well formed, and probably the best of the class. Free. Each $15 \mathrm{c}$, per $10, \$ 1.25$.

Red Hussar-Dark rich red, an excellent bloomer and dependable. Each $15 \mathrm{c}$, per $10, \$ 1.25$.

Queen Victoria-Pure golden yellow, and one of the freest bloomers. Excellent. Each $15 \mathrm{c}$, per 10, $\$ 1.25$.

One each of the above three, $40 \mathrm{c}$, mail prepaid $45 \mathrm{c}$.

One each of six varieties, $75 \mathrm{c}$, mail prepaid, $90 \mathrm{c}$.

One each of 12 varieties, $\$ 1.50$, mail prepaid $\$ 1.75$.

\section{TWENTIETH CENTURY DAHLIAS}

These are the single flowers of the Dahlia family, and are gain. ing favor all the time.

Crimson Century-Deep rich crimson, a beauty. Each 20c, per $10, \$ 1.75$.

Pink Century-Delicate shell pink, fine. Each $30 \mathrm{c}$, per 10, $\$ 2.50$.

20 th Century-Rose crimson, well known and valuable. Each 15c, per $10, \$ 1.25$.

\section{POMPOM DAHLIAS}

The minature family of dahlias, ranging from 1 inch to two or two and a half inches in diameter. They are noted for being profuse bloomers, usually dwarfish growers but flowers borne on long stiff stems, making them desirable for cutting. Preferred to all others by many.

Alewine-Delicate blush, almost white, fine. 
Brunette-Crimson, with white blotches.

Highland Mary-Almost too large for Pompom type. Pink, with white center. The most profuse bloomer on our grounds. From July to November, a solid mass of bloom, extra good.

Pompom Dahlias, earh $15 \mathrm{c}$, per $10 \ldots \ldots \ldots \ldots \ldots 1.20$

One each of the above, $40 \mathrm{c}$, prepaid mail.......... .45

One each of 6 varieties, 80 , prepaid mail.......... .90

One each of 10 varieties, $\$ 1.25$, prepaid mail....... 1.40

One each of 20 varieties, $\$ 2.50$, prepaid mail...... 2.80

We have a few mixed dahlias, many of them of the finest varieties, each 10c, per $1075 \mathrm{c}$. Postage, if by mail, $2 \mathrm{c}$ each extra.

\section{Shade and Ornamental Trees}

We have a very complete assortment of shade trees and give descriptions of those varieties not so generally known. Our trees are all nursery grown transplanted stock with good roots.

Birch-American and European White-The most charming and graceful shade trees grown.

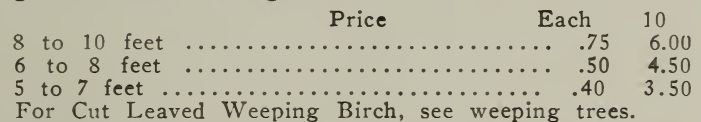

Beech-Purple Leaved, or Copper Beech-The copper beech is one of the most striking foliage trees grown. Purple leaves in summer, changing to a copper brown in fall. Make fine specimen trees.

Catalpa Speciosa-We grow large quantities of these, and gather the seed ourselves from genuine Speciosa trees. Makes a beautiful flowering tree, up right growth and large round leaves. The genuine Speciosa Catalpa is very rapid in growth, and without question is the most valuable hardy timber tree that we can grow. Planted very extensively for railroad ties and posts. The most durable of any timber known for that purpose. Makes a fine finishing lumber. Our stock is the genuine hardy Speciosa. We have a large quantity of very fine small seedlings.

\begin{tabular}{|c|c|c|c|}
\hline $\begin{array}{l}\text { to } 7 \text { feet } \ldots \\
\text { to } 8 \text { feet } \ldots \\
\text { to } 10 \text { feet } \\
\text { to } 12 \text { feet } \ldots \\
\text { to } 12 \text {. }\end{array}$ & $\begin{array}{r}\text { Each } \\
. \quad .25 \\
. \quad .30 \\
. \quad .40 \\
. \quad .55\end{array}$ & $\begin{array}{l}10 \\
2.00 \\
2.50 \\
3.50 \\
4.50\end{array}$ & $\begin{array}{c}100 \\
14.00 \\
18.00 \\
\ldots \ldots \\
\ldots\end{array}$ \\
\hline igs & $\begin{array}{l}10 \\
. \quad .30\end{array}$ & $\begin{array}{l}100 \\
2.00\end{array}$ & $\begin{array}{l}1000 \\
15.00\end{array}$ \\
\hline hes, stocky & .20 & 1.50 & 10.00 \\
\hline
\end{tabular}

Bungei-Globe Headed Catalpa-Grafted on C. Speciosa 6 feet above the ground making an umbrella or globe shaped head. These trees have many ornamental merits.

$$
\text { Price Each } 10
$$

Strong 2 year heads $\ldots \ldots \ldots \ldots \ldots \ldots \ldots, 1.50 \quad 12.50$

European Bird Cherry-Makes a beautiful tree 15 to 20 feet in height, flowers and leaves both better than our native wild cherry.

$\begin{array}{rrr}\text { Price. Each } 10 & 0\end{array}$

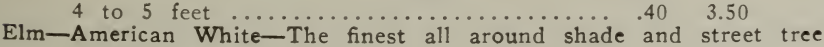
grown.

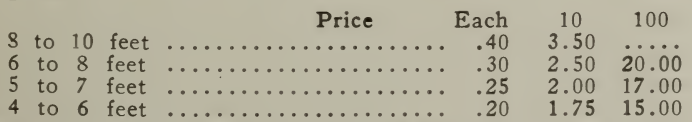

- Recommended by the Illinois State Horticultural Sosiety. 
*Horse Chestnut-A most ornamental tree for both flowers and foliage. One of the very desirable trees.

Price

Each 10

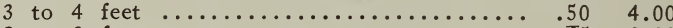

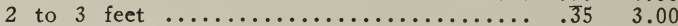

Kentucky Coffee Tree-Probably no tree we grow gives a more charming tropical effect than the Kentucky Coffee tree with its beautiful long fern-like leaves. Very fine for shade and ornamental planting.

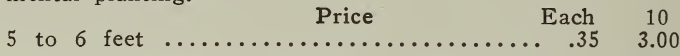

Japanese Varnish Tree-Koelreuteria Paniculata-A beautiful low growing handsome tree with bright glossy foliage.

Price. Each 10

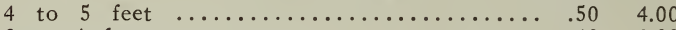

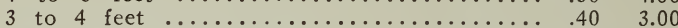

Larch-European Larch-The European larch is much hardier in this climate than the American, making a much handsomer tree There is probably no more beautiful tree than the larch, with its fine feathery foliage. They are very rapid growers and are not planted nearly as much as they should be. They are excellent for wind breaks, besides making fine individual specimens.

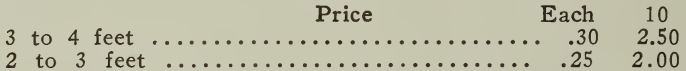

Linden-American and European-Splendid trees, quick growing, and the sweet blossoms in June attract the bees.

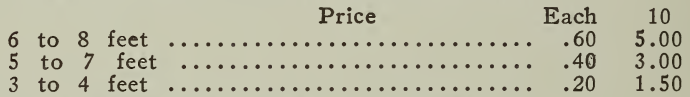

Maple-Box Elder-One of the hardiest trees grown.

Price Each

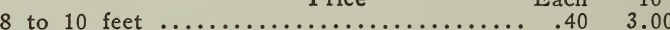

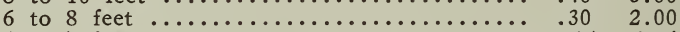

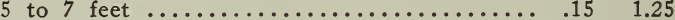

California Maple-A form of box elder considered a little more ornamental than the common box elder.

Price. Each 10

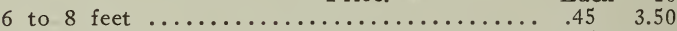

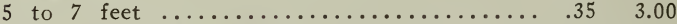

Soft or Silver Maple-Very quick growers and a popular tree.

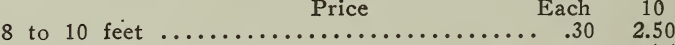

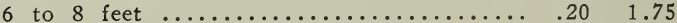

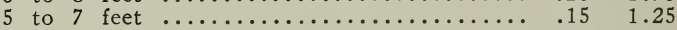

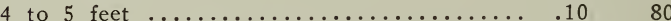

Hard or Sugar Maple-Same price as Norway maple.

* Norway Maple-Similar to the Sugar or Hard Maple, more rapid in growth, and more uniform in shape. A magnificent shade and street tree.

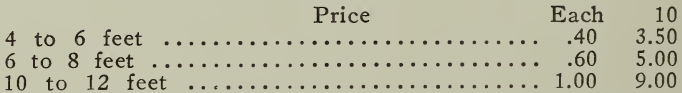

Weirs Cut Leaved Maple-A form of soft maple with handsome finely cut leaves, a very ornamental and desirable tree.

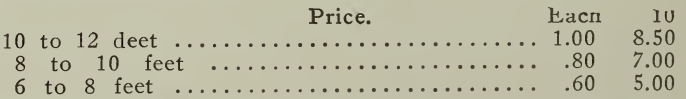

Mountain Ash-American and European Mountain Ash-The finely cut foliage of the mountain ash together with their clusters of blossoms in the early summer, and great quantities of brilliant orange colored berries in the fall make them a very ornamental and pleasing tree for the yard. 


8
8 to 10 feet $\ldots \ldots \ldots \ldots \ldots \ldots \ldots \ldots \ldots \ldots \ldots \ldots \ldots \ldots$

Mulberry-Russian (see fruits)-Since ornamental hedges are becoming so popular the Russian Mulberry will be much used for this purpose. It makes an excellent hardy hedge which can be trimmed to any desired shape. For price of Mulberries see page 7 .

Weeping Russian-See Weeping Trees.

Poplar-Carolina Poplar-The most rapid grower of all shade trees and much in demand. Valuable for quick and temporary sharle in street or yard. It seems to be fashionable for some people to denounce the Carolina Poplar. Still there are more of these trees sold probably than any other shade tree. They are a valuable tree if properly used. Plant them for quick shade interspersed with other kinds for permanent shade. Then cut them out when they crowd.

$$
\text { Price Each } 10
$$

16 to 20 feet, 3 to 4 in. diameter.................. $1.50 \quad 12.50$

14 to 16 feet, $21-2$ to 3 in. diameter............... $1.00 \quad 9.00$

12 to 14 feet, 2 to $21-2$ in. diameter............ $.70 \quad 6.00$

10 to 12 feet, 13.4 to 2 inch stems ......... $55 \quad 5.00$

10 to 12 feet, $11-4$ to $13-4$ inch stems .... .45 4.00

8 to 10 feet ................................... 35

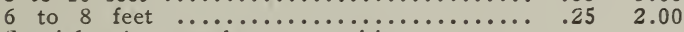

Special prices on large quantities.

Van Gerts, or Golden-A typical poplar similar in style of growth to the Carolina Poplar, but grows more slowly and has golden leaves.

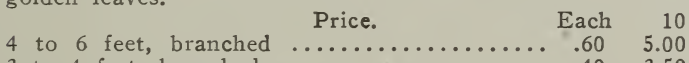

3 to 4 feet, branched ........................... $40 \quad 3.50$

Volga Poplar-One of the newer varieties of poplar, which grows similar to the Carolina, more trim and a handsomer tree.

Price Each 10

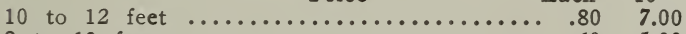

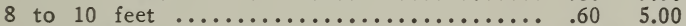

7 to 8 feet $\ldots \ldots \ldots \ldots \ldots \ldots \ldots \ldots \ldots \ldots \ldots . .40 \quad 3.50$

Bolleana Poplar-An upright silver leaved poplar, grows tall and slender similar to the Lombardy poplar and much more satisfactory than the Lombardy where that style is desired.

\begin{tabular}{|c|c|c|}
\hline 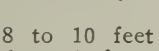 & $\begin{array}{c}\text { Price. } \\
\ldots \ldots \ldots \ldots \ldots \ldots \ldots\end{array}$ & $\begin{array}{c}\text { Each } \\
.75\end{array}$ \\
\hline to 8 fee & $\ldots \ldots$ & .60 \\
\hline
\end{tabular}

Plum-Prunus Pissardi-Purple leaved plum-Very ornamental, deep purple foliage, a striking and handsome tree.

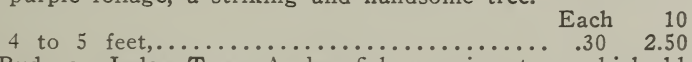

Red Bud, or Judas Tree-A dwarfish growing tree which blossoms very early in spring before the leaves appear. The trees in blossom are a solid mass of flaming red, very striking and ornamental.
Price.
Each 10

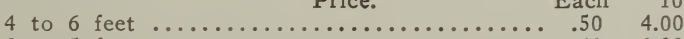

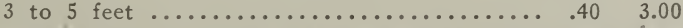

Sycamore-A valuable native tree, much used for street plánting and shade. Its light colored bark making a pleasant contrast.

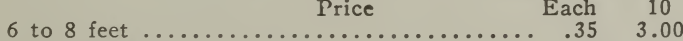

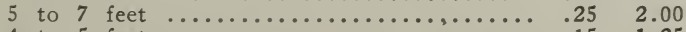

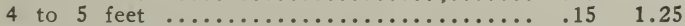

Tulip Tree-Liriodendron Tulipifera-In the early summer the delightful fragrant blossoms of the Tulip tree lasting several weeks together with its strong upright growth and beautiful dark green foliage make this one of the grandest of our native trees. We have a large stock of splendid trees.
8 to 10 feet $\ldots \ldots \ldots \ldots \ldots \ldots \ldots \ldots \ldots \ldots \ldots . .45$
8 to 10 feet $\ldots \ldots \ldots \ldots \ldots \ldots \ldots \ldots \ldots \ldots \ldots . .45$

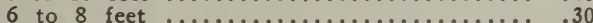


Willow-Cromwell or Cabra-The well known and prized pussy willow so attractive in early spring.

Price Each 10

5 to 7 feet $\ldots \ldots \ldots \ldots \ldots \ldots \ldots \ldots \ldots \ldots . .30 \quad 2.50$

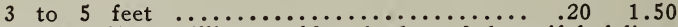

Golden-The brilliant golden bark and beautiful foliage make this a decidedly attractive tree in both summer and winter.

Price

Each 10

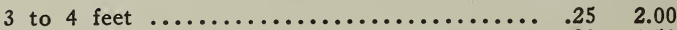

2 to 3 feet $\ldots \ldots \ldots \ldots \ldots \ldots \ldots \ldots \ldots \ldots \ldots \ldots \ldots . .20 \quad 1.50$

\section{Weeping Trees}

*Cut Leaved Weeping Birch-Forty feet-As a specimen tree for the lawn with its fine feathery foliage and drooping habit together with its clean white bark, makes this a very popular tree.

Price

$$
\text { Each } 10
$$

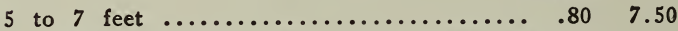

Russian Mulberry-Eight feet-These trees are not only ornamental but bear large quantities of fruit that is much liked by the birds as well as most people. A very distinct tree, with its long slender branches that sweep the ground. Can be trained over a seat or wall and makes a beautiful effect.

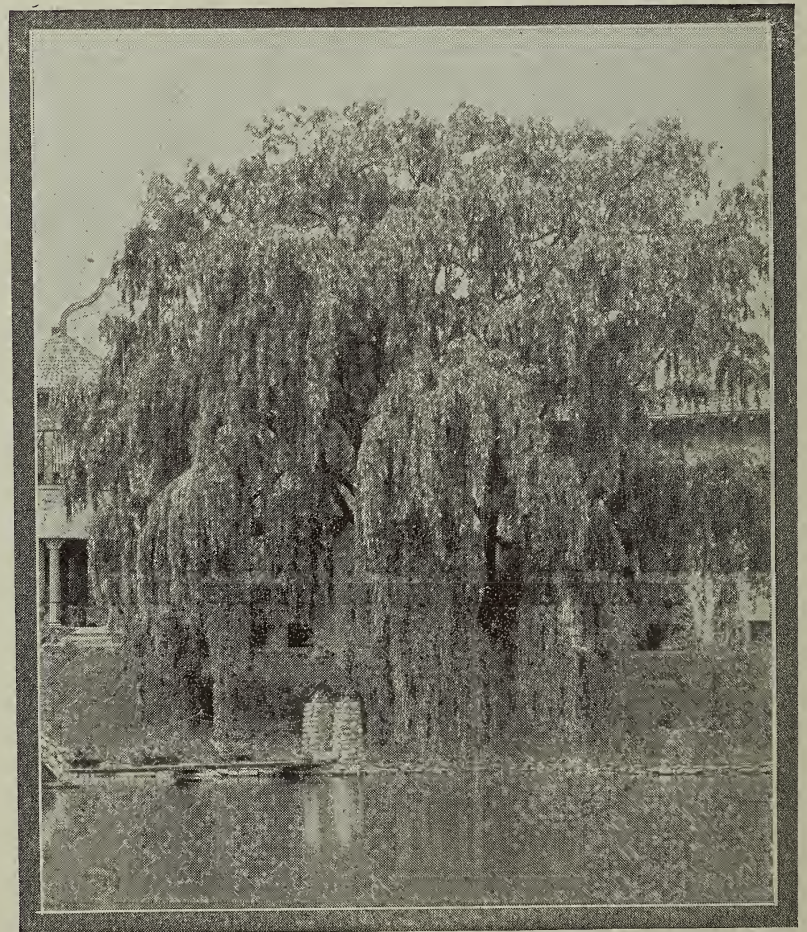

NAPOLEON WEEPING WILLOW, THE FINEST IN ITS CLASS

"Recommended by the Illinois State Horticultural Society. 


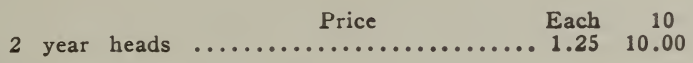

Willow.

Kilmarnock-Eight feet-These trees are grafted about 6 or 7 teet high and the trailing branches reach to the ground. Unique little trees for special purposes.

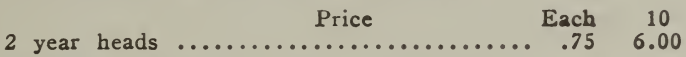

Napoleon-Forty feet-This variety came to us from a neighbor, Fathern Sherman, who received it direct from Napoleon's grave on the Island of St. Helena, through a missionary friend re. turning from Africa. Probably no trees in the world were ever more famous than these weeping willows. Perfectly hardy, and the long streamers often 20 feet in length and no larger than a lead pencil, make them one of the most pictur. esque and striking trees grown.

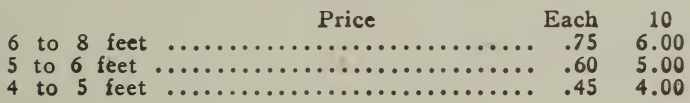

\section{Evergreens}

The secret of transplanting evergreens successfully lies in never al. lowing the roots to become the least bit dry. A few minutes exposure to wind or sun, will dry up the small fibrous roots changing the sap to a hard resinous substance, and no amount of care and attention will ever make them grow after this happens.

They can be shipped around the world with safety however if they are not allowed to ever become dried. We dig evergreens when so ordered with a ball of earth attached to the roots, and burlap them in this way at an extra charge of $10 \mathrm{c}$ each. We use every precaution in digging and handling evergreens to keep them always moist.

All two and three times transplanted.

Aborvitae-American-Flat leaved ornamental, suitable also for hedge.

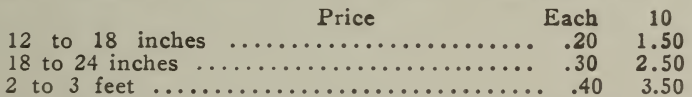

Austrian Pine-Strong growing, rather coarse, long heavy needles, one of the best.

\begin{tabular}{|c|c|c|}
\hline & Price & Each \\
\hline $\begin{array}{l}18 \text { to } 24 \text { inches } \\
2 \text { to } 3 \text { feet ... }\end{array}$ & & .30 \\
\hline to 4 feet & $\ldots \ldots \ldots \ldots$ & .50 \\
\hline
\end{tabular}

Scotch Pine-Similar to Austrian but more compact, a splendid hardy tree. ...
12 Price 18 Each 10

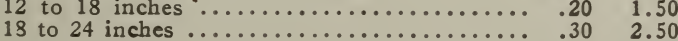
2 to 3 feet .......................40 3.50

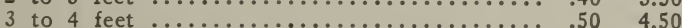

White Pine-One of the most graceful and refined of all the tall growing evergreens.

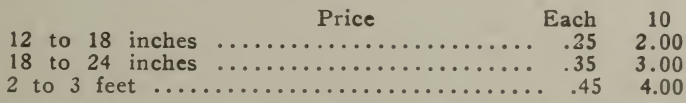

Jack Pine-A handsome very rapid growing hardy pine, that does well under conditions where other evergreens will not grow.

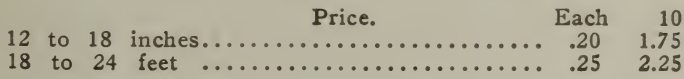


Mahonia Aquafolia-See shrubs.

Larch-See ornamental trees.

Spruce, Norway-The well known spruce, much used as windbreak.

\begin{tabular}{|c|c|c|c|c|}
\hline 18 to 24 inches & Price & Each & $\begin{array}{r}10 \\
50\end{array}$ & 100 \\
\hline 12 to 18 inches & ${ }^{\prime} \ldots \ldots \ldots$ & $\begin{array}{l}.30 \\
.25\end{array}$ & $\begin{array}{l}2.50 \\
1.75\end{array}$ & \\
\hline
\end{tabular}

Retinispora-These dwarfish evergreens from Japan are among the most ornamental we have. Their feathery foliage, and compact growth always attract attention.

Plumosa-A light green, very fine.

Price Each 10

12 to 18 inches ..................... .50 4.00

Plumosa Aurea-Ends of branches tipped with gold, making beautiful contrast with the dark green.

Price

12 to 18 inches ....................... .50 4.00

Taxus-Cuspidata, (True Japanese Taxus).-This form of Taxus or Yew, is the true Japanese, and the only Yew that will stand our trying climate. They are going to become very popular when known. An exceptionally fine Dwarfish growing specimen plant.

Price

Imported with ball of earth attached, 18 to 24 inches, each, $\$ 1.50$, per $10, \$ 12.50$.

Juniper, Virginica, Red Cedar-This is one of our few native evergreens and does exceedingly well in Illinois.

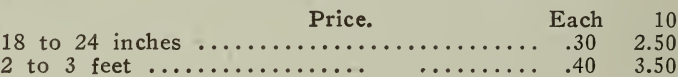

Juniper, Blue-This is a new form of the American Rer Cedar, rapid growth, foliage a bright steel blue, one of the most beautiful evergreen we have ever seen. New and rare.

\section{Price.}

Grafted plants, 2 feet, specimens balled, each,....... 1.50

\section{WHAT TO DO WHEN YOUR PLANTS COME}

As soon as you receive the stock it should be unpacked, and the roots puddled. If the trees are dried or shriveled in the least, place them in water at once, allowing them to be completely covered for twelve to twenty-four hours. In case you should not want to plant out as soon as unpacked, heel-in in moist soil; never allowing the roots to become dry or failure will likely result.

Remove all broken or extra long roots with a sharp knife, cutting from below outwards. One-year old peaches and apple trees should be cut back to a naked stem, but do not cut off buds next to body. Two-year old trees should have their branches cut back at least half their length, the lower shorter than those above.

Care should be taken to have ground thoroughly plowed and subsoiled to a depth of at least fifteen inches. The holes should be sufficiently broad and deep so that the roots can be straightened to their natural position without cramping. Two inches or more of fresh surface dirt should be placed in the bottom of the hole in which to bed the roots; set the tree two or three inches deeper than it stood in the nursery row, allowing it to lean a considerable to the southwest; fill in among the roots with mellow soil and pack down firmly with the foot. When the hole is about half full, if the ground is dry, pour in enough water to thoroughly moisten the earth, fill the hole with dirt; pressing firmly, especially around the stem. Leave the surface smooth and mellow and keep well pulverized during the growing season. Never pour water on top of the ground, but dig trenches around the tree or insert a tile, about fifteen inches from the stock, slanting towards the roots, and fill with water every evening until the ground is thoroughly saturated below the roots. Partial surface watering during a dry spell does more injury to young transplanted stock than good. We strongly advise mulching for winter protection. Be sure to loosen the wire label before planting.

AUGUSTINE \& CO., Normal, III. 
Common names in Capitals.

Achillea $\ldots \ldots \ldots \ldots \ldots \ldots .34$

ADAMS NEEDLE .......35

ALMONDS ............... 19

ALTHAEA $\quad \ldots \ldots \ldots \ldots . \ldots 19$

Amorpha Fruticosa .......22

Ampelopsis $\ldots \ldots \ldots \ldots \ldots . \ldots 31$

Anemone $\quad \ldots \ldots \ldots \ldots \ldots . . . .35$

APPLES $\ldots \ldots \ldots \ldots \ldots \ldots .4$

APRICOTS $\ldots \ldots \ldots \ldots \ldots \ldots 5$

Aquilegia $\ldots \ldots \ldots \ldots \ldots . \ldots 36$

ARBORVITAE $\quad \ldots \ldots \ldots \ldots .45$

Aristolochia Sipho .........30

ASPARAGUS $\ldots \ldots \ldots \ldots .18$

ASTER $\ldots \ldots \ldots \ldots \ldots \ldots . \ldots 36$

BARBERRY $\ldots \ldots \ldots \ldots \ldots 19$

BEECH $\ldots \ldots \ldots \ldots \ldots \ldots . .41$

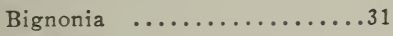

BIRCH $\quad \ldots \ldots \ldots \ldots \ldots \ldots . .41$

BIRCH WEEPING .....44

BIRD CHERRY ........41

BITTER SWEET .......29

Bocconia Cordata .........36

BLANKET FLOWER .....36

BLACKBERRIES ........14

BOX ELDER .........42

BRIDAL WREATH .....27

BLCKTHORN .............19

Ruddleia Variabilis ......20

Calycanthus ............20

Caragana Arborescens ....20

Caryopteris Mastacanthus ...36

C.ATALPA $\ldots \ldots \ldots \ldots \ldots .41$

Celastrus Scandens .......29

CHERRIES $\ldots \ldots \ldots \ldots \ldots \ldots$

CHRYSANTHENIU II .....36

CLAIMS $\quad \ldots \ldots \ldots \ldots \ldots \ldots 2$

CLEMATIS .........29, 36

COLLMBINE $\ldots \ldots \ldots \ldots \ldots 36$

CUPPER BEECH ......4.

CORAL BERRY ........29

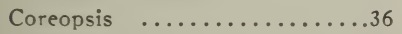

Cornus .................20

Corylus ..............21

CRABAFPIES ...........

CRANBERRY- High Bush 26

Crataegus $\quad \ldots \ldots \ldots \ldots \ldots 20$

CURRANT, FLOWERING...20

CURRANר $\$$............15

DAHLIAS $\ldots \ldots \ldots \ldots \ldots . \ldots 39$

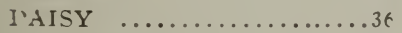

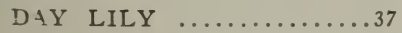

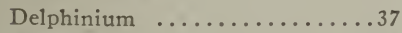

Deutzia

. .21
DEWBERRIES ...........14

Dianthus Barbatus ........36

Dianthus Plumarius .......38

Diervilla ..............20

DISCOUNTS ........... 3

DIST ANCE FOR PLANT.

ING.............47

DOGWOOD .............20

DUTCHMAN'S PIPE ......30

IIWARF PEARS ........12

Elaeagnus $\ldots \ldots \ldots \ldots \ldots \ldots . \ldots 24$

ELDER $\ldots \ldots \ldots \ldots \ldots \ldots 21$

ELM $\ldots \ldots \ldots \ldots \ldots \ldots \ldots \ldots 41$

Euonymus $\quad \ldots \ldots \ldots \ldots \ldots . . .21$

Euonymus Radicans .......30

EVERGREENS .........45

Exochorda $\ldots \ldots \ldots \ldots \ldots 24$

FALSE INDIGO .......22

FILBERT .............21

FLAME FLOWER ........39

FLOWERING PLUM .....24

Forsythia $\ldots \ldots \ldots \ldots \ldots \ldots 22$

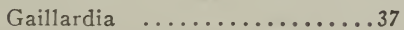

GARDEN ROOTS .........18

GLOBE FLOWER .......22

GOLDEN BELL .........22

GOLDEN GLOW ..........37

GOOSEBERRIES ..........15

GRAPES $\ldots \ldots \ldots \ldots \ldots \ldots$

GRASS ORNAMENTAL ...39

HACKBERRY $\ldots \ldots \ldots \ldots .442$

Hammamelis ...........29

Helianthus ..............38

Heliopsis ................38

Hemerocallis .............37

Hibiscus Syriacus .........19

HONEYSUCKLE BUSH ...22

HONEYSUCKLE, CLIMB. ING $\ldots \ldots \ldots \ldots \ldots \ldots \ldots . . . .30$

HORSE CHESTNUT .....42

HORSE RADISH ........18

HYDRANGEA $\ldots \ldots \ldots \ldots .22$

INSPECTION CERTIFI.

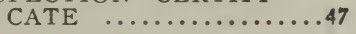

IRIS $\quad \ldots \ldots \ldots \ldots \ldots \ldots . \ldots . \ldots . . .39$

IVY $\ldots \ldots \ldots \ldots \ldots \ldots \ldots \ldots . . . \cdots$

JUNE BERRIES .........14

JUNIPER $\ldots \ldots \ldots \ldots \ldots \ldots .46$

KEN'TCKY COFFEE

TREE .............42

Kerria Japonica ..........22

Koelreuteria ............442

KUDZU VINE ............31 


\section{INDEX - Continued}

Common names in Capitals.

LANDSCAPE GARDEN-

ING $\ldots \ldots \ldots \ldots \ldots \ldots \ldots, 2$

LARCH $\ldots \ldots \ldots \ldots \ldots \ldots . \ldots 42$

LARKSPUR $\ldots \ldots \ldots \ldots \ldots . . . .37$

Ligustrum $\ldots \ldots \ldots \ldots \ldots \ldots . . .24$

LILAC $\ldots \ldots \ldots \ldots \ldots \ldots .23$

LILY OF THE VALLEY...39

LINDEN .............44

Liriodendron Tulipifera......43

Lonicera Upright ........22

Lonicera Climbing $\ldots \ldots \ldots \ldots 30$

Lychnis ..................38

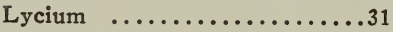

Mahonia .................23

MALLOW ................39

MAPLE ..............44

MATRIMONY VINE .....31

MOUNTAIN ASH .......44

MULBERRIES ........6.43

MULBERRIES WEEPING..44

\section{NUMBER OF PLANTS}

TO ACRE ............47

NUT TREES $\ldots \ldots \ldots \ldots \ldots 18$

PAEONIA ...............38

PEACHES ...............?

PEARL BUSH $\ldots \ldots \ldots \ldots .24$

PEARS $\ldots . \ldots \ldots \ldots \ldots \ldots 10-11$

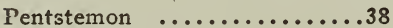

PERSIMMONS ...........19

Phalaris .................39

Philadelphus $\ldots \ldots \ldots \ldots \ldots \ldots 27$

PHLOX HARDY ..........38

Physostegia $\quad . . \ldots \ldots \ldots \ldots . . .638$

PIE PLANT $\ldots \ldots \ldots \ldots \ldots 18$

PINE $\ldots \ldots \ldots \ldots \ldots \ldots \ldots .45$

FINKS, HARDY $\ldots \ldots \ldots . .38$

PLUME POPPY ...........36

PLUM, ORNAMENTAL $\ldots 43$

PLUMS $\ldots \ldots \ldots \ldots \ldots \ldots \ldots \ldots \ldots$

POPLAR $\ldots \ldots \ldots \ldots \ldots \ldots . \cdots 43$

PRIVET ................24

Prunus Pissardi ...........43

Prunus Triloba ............24

Pueraria ..................31

Pyrethrum ...............37

Pyrus Japonica ...........25

QUINCE $\ldots \ldots \ldots \ldots \ldots \ldots 13$

QUINCE, FLOWERING ...25

RED BUD .............43

RED CEDAR ............46

RASPBERRIES $\ldots \ldots \ldots \ldots 14$

RED HOT POKER.......39

RESPONSIBILITY .......2

Retinispora $\ldots \ldots \ldots \ldots \ldots . \ldots 46$
Rhamnus ................19

RHUBARB $\ldots \ldots \ldots \ldots \ldots \ldots 18$

Rhus $\ldots \ldots \ldots \ldots \ldots \ldots \ldots . . .28$

Ribes Aureum ..........20

Rosa Rugosa ..............33

ROSES ....................

Rudbeckia ..............38

RUSSIAN OLIVE ........24

Sambucus $\ldots \ldots \ldots \ldots \ldots \ldots 21$

SERVICE BERRY ........14

SHIPPING BY MAIL.......3

SHIPPING DIRECTIONS $\ldots 2$

SIBERIAN PEA $\ldots \ldots \ldots \ldots 20$

SNOW BALL ...........26

SNOWBERRY $\ldots \ldots \ldots \ldots \ldots 28$

SPICE BUSH $\ldots \ldots \ldots \ldots .20$

SPIREA $\ldots \ldots \ldots \ldots \ldots \ldots .26 .27$

SPIREA, BLUE ..........36

SPRUCE ..............46

STAFF VINE ...........29

STRAWBERRIES $\ldots \ldots \ldots \ldots 17$

STRAWBERRY TREE ....21

SUBSTITUTION...$\ldots \ldots \ldots 2$

SUDDUTH PEAR ........10

SUMACH $\ldots \ldots \ldots \ldots \ldots .28$

SUNFLOWER, HARDY ...37

SWEET WILLIAM .......36

SYCAMORE .............43

Symphoricarpos $\ldots . \ldots \ldots \ldots 28$

SYRINGA ..............27

Syringa Vulgaris $\ldots \ldots \ldots \ldots .23$

TAMARISK $\ldots . \ldots \ldots \ldots .29$

Tamarix ..............29

Taxus Cuspidata ..........46

TERMS $\quad \ldots \ldots \ldots \ldots \ldots \ldots \ldots 2$

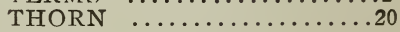

THORN SILVER ........24

TICKSEED ...............36

TREATMENT OF

PLANTS ............46

Tritoma ..................39

TRUMPET VINE ........31

TULIP TREE..$\ldots \ldots \ldots \ldots 43$

Viburnum $\ldots \ldots \ldots \ldots \ldots .26$

VARNISH TREE $\ldots \ldots \ldots .42$

WALNUT TAPANESE ..... 19

WEIGELIA $\ldots \ldots \ldots \ldots \ldots 29$

WEIGHT OF PLANTS....47

WILLOW .............44

WILLOW, WEEPING $\ldots \ldots 45$

WISTARIA $\ldots \ldots \ldots \ldots \ldots . . . . .31$

WITCH HAZEL .........29

YARROW ...............34

YEW JAPANESE...$\ldots \ldots .46$

Yucca Filamentosa .........35 


\section{ORDER SHEET \\ Augustine \& Co., Nurserymen \\ NORMAL, ILLINOIS \\ ESTABLISHED 1867}

READ INSTRUCTIONS ON FIRST PAGE OF CATALOGUE. WRITE PLAINLY.

FORWARD TO

Name of Person

(Ladies will please sign Miss or Mrs.)

Name of Postoffice

Name of County

Name of State

Shipping Address

How Ship and Route

(Freight, Express or Mail)

Date you wish orders shipped
Date

Amt. Enclosed

P. O. Order - \$

Draft - . - $\$$

Ex. Money Ord. \$

Cash - - . \$

Total - $\$$

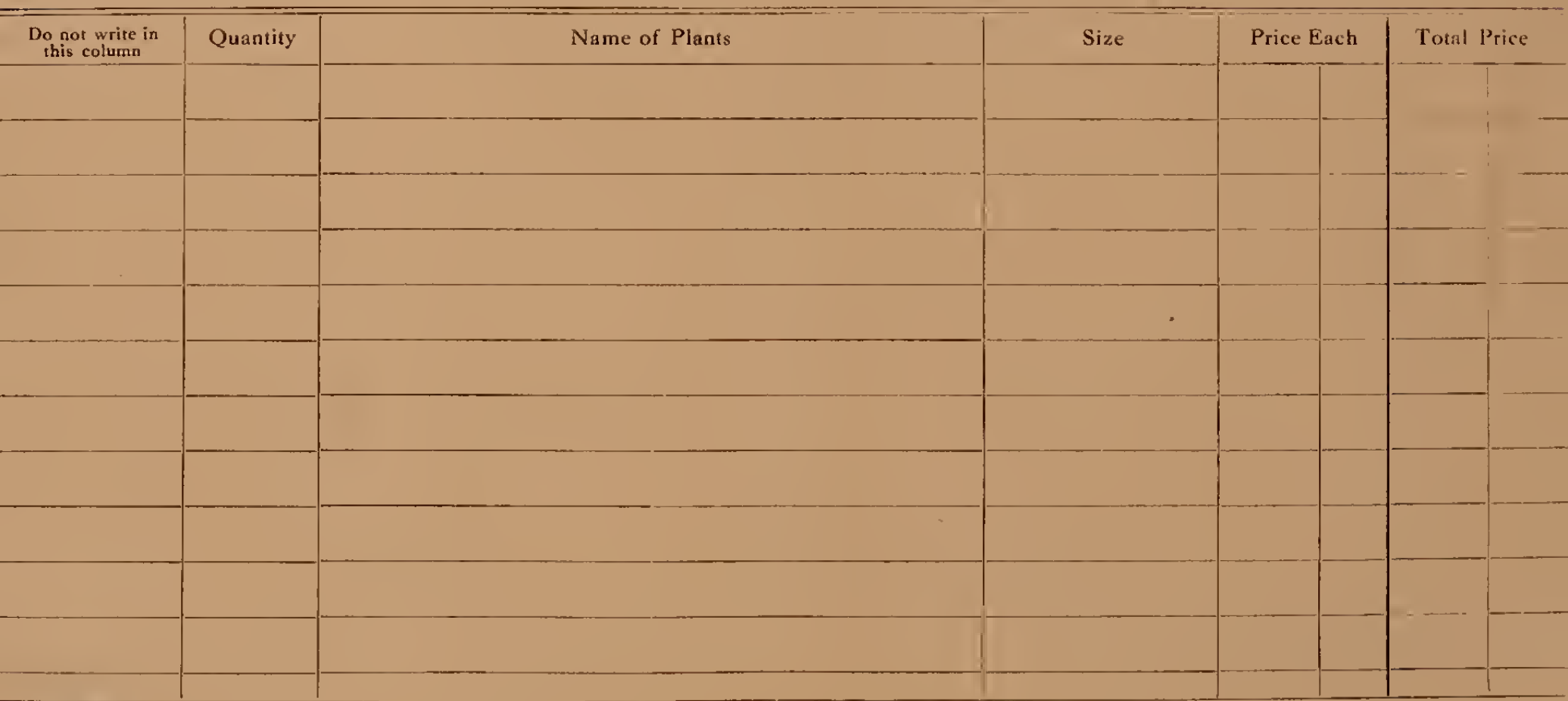



In sending you our 46 th annual catalogue we wish to thank you for the many kind words of appreciation we have received from you the past year, and the increased business you have sent us.

We would like to write each of you a personal letter, instead of this circular letter, but that of course is impossible.

However, we wish to again assure you that we appreciate your orders and are going to do everything in our power to please you, and give you the most value for the money.

This catalogue is our salesman, the only one we have, except the recommendations of our many friends. It costs us 2 cents to send it to you; with it you can get the actual facts regarding practically all the most suitable trees and plants for the middie west at least.

If we were to send a salesman to see you, an average one would cost for his expenses and salary at least $\$ 10.00$ per day. That extra expense would have to be figured in on the selling price of the stock. The salesman might or might not stretch the truth here and there to make a sale. The catalogue will give you in a condensed form just what you want to know, and you can depend upon it.

In ordering from us you get your stock direct from the growers with but the one small profit they make added. It is fresh and full of life, and true to name.

Our experience, sincecutting out thetree peddling some 20 years ago, demonstrates that there is getting to be a larger class of discriminating buyers who want their money's worth and, above all, what they order. The average man has got to take the word of the manhe buys from as to whether he is going to get the varieties he orders or not. Is it safer to buy of some one you never saw before and probably never will again, or some old reliable nursery that has been in business in the same place for nearly half a century, that you can always find right there?

We have a number of customers on our books whose father and grandfather before them were customers of ours, and although we like to make new friends and get new customers all the time, yet this trade and the confidence it shows we appreciate very much.

We believe we have the finest stock, the largest assortment and the most of it, to take care of our trade with this year, that we ever grew and we know it will please you. The men who have the filling and handling of your orders are men who have been raised up in the business with us, they have had years of experience and are thorough nurserymen. They know good stock, and how to handle and pack it so that it will reach you in the best possible condition, full of life and vigor.

of late years more and more attention is being paid to Landscape Gardening, and the ornamentation of the home grounds. Our stock of ornamentals is very complete and large and we are prepared to do all kinds of Landscape work. We have put out many of the largest, and finest plantings in the state, and will be glad to assist you in any way we can.

Send in your orders early, when we have more time to handle and prepare your stock. To encourage early orders we give very liberal discounts, that in most instances are enough or more to pav the freight or express.

If we fail to please you in any way, tell us about it, and when we do, tell your friends. Write to us anyway, we like to get your letters.

Sincerely,

AUGUSTINE \& CO., Normal, Ill. 

Feei Nona

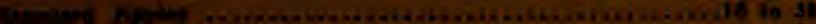

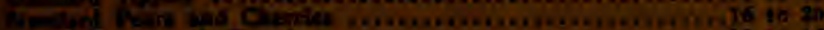

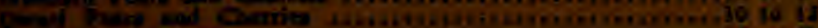

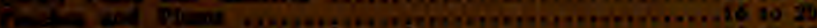

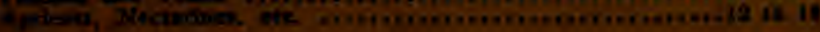

Pown Prents
Apant

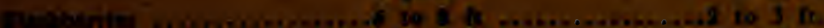

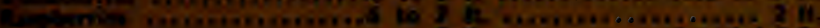
arrofemiel

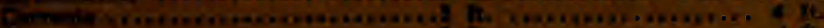

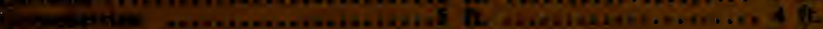

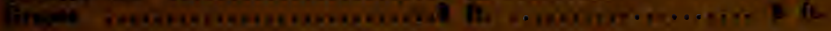

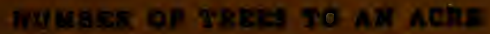

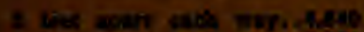

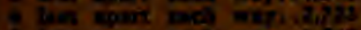

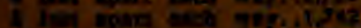

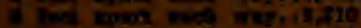

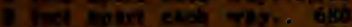

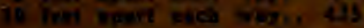

17 fect asave cach wer.....tub is tect ederi kach way......2us 38 ieet epart each war......135

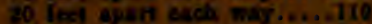
25 let apert sach mar.... 79 30, for apart cach way..... 59

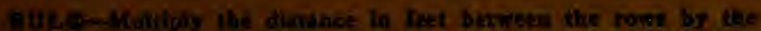

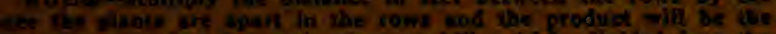

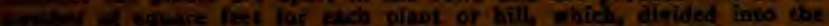

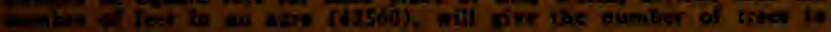
Nate 2 is

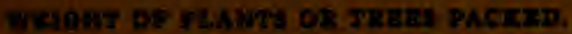

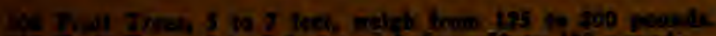

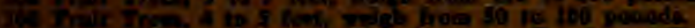

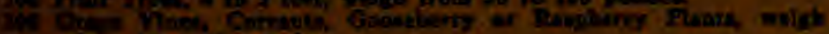

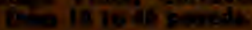

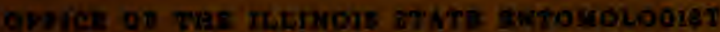

alo 101

Urbenas Filineia Getobex 6. 1962.

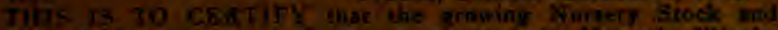

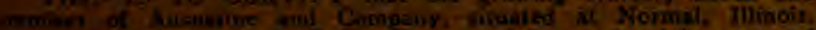

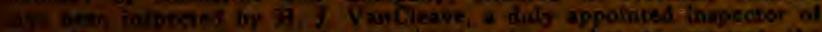

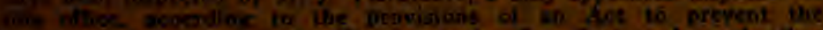

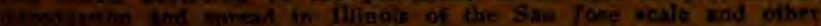

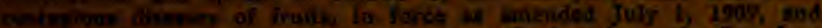

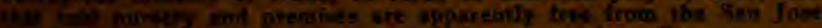

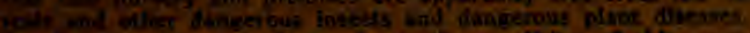

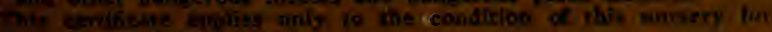

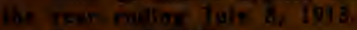

\section{?. ицени}

Shint lougetion

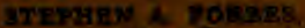

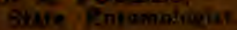




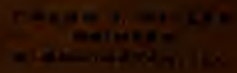

